PRACE GEOGRAFICZNE

zeszyt 162, 2020, 89-123

doi: 10.4467/20833113PG.20.014.13101

Instytut Geografii i Gospodarki Przestrzennej UJ

Komisja Geograficzna, Polska Akademia Umiejętności

Wydawnictwo Uniwersytetu Jagiellońskiego

\title{
OCENA JAKOŚCI PRZESTRZENI PUBLICZNYCH III KAMPUSU UJ Z UŻYCIEM TECHNIKI CROWDSENSINGU
}

\author{
Jarostaw Dziatek, Barttomiej Homiński, Magdalena Miśkowiec, \\ Agnieszka Świgost-Kapocsi, Krzysztof Gwosdz
}

\section{Quality assessment of public spaces of the Jagiellonian University Third Campus using the crowdsensing technique}

Abstract: The article aims to assess the quality of public spaces of the Third Campus of the Jagiellonian University and to determine to what extent the mobile crowdsensing survey method is useful in this respect. Public spaces are nowadays considered the key elements of the university campus structure. Their appropriate shaping and management fosters social interactions between different user groups, which should consequently strengthen creativity and interdisciplinarity within the university milieu. Our paper presents contemporary trends in the campus planning and organisation. In the empirical part, the quality of selected public spaces (main avenue, squares and courtyards, and green areas) was determined based on the behaviour of campus users as observed by participants of the crowdsensing study. These results were confronted with the visual material and comments of the study participants, as well as with the expert assessment of the authors. In the final part, activities aimed at improving the quality of public spaces of the campus were proposed.

Keywords: campus, public space, crowdsensing, Epicollect5, Jagiellonian University

Zarys treści: Celami niniejszego artykułu są ocena jakości przestrzeni publicznych III Kampusu UJ oraz określenie, w jakim stopniu przydatna jest w tym zakresie metoda crowdsensingowego badania ankietowego z użyciem aplikacji mobilnej. Przestrzenie publiczne 
uznawane są współcześnie za kluczowe elementy organizacji kampusów uczelni. Ich odpowiednie ukształtowanie i zagospodarowanie sprzyja interakcjom społecznym między różnymi grupami użytkowników, co w konsekwencji powinno służyć wzmacnianiu kreatywności i interdyscyplinarności w środowisku uniwersyteckim. W tekście przedstawiono współczesne trendy w zakresie planowania i funkcjonowania kampusów. W części empirycznej na podstawie obserwacji zachowań użytkowników kampusu, dokonanych przez uczestników badania crowdsensingowego, określono jakość wybranych przestrzeni publicznych: głównej alei, placów i dziedzińców oraz terenów zielonych. Wyniki te skonfrontowano z materiałem i komentarzami uczestników badania oraz z ocená artykułu. W końcowej części zaproponowano kierunki działań w zakresie poprawy jakośc przestrzeni publicznych badanego kampusu.

Stowa kluczowe: kampus, przestrzeń publiczna, crowdsensing, Epicollect5, Uniwersytet Jagielloński

\section{Wstęp}

Kampusy stanowią rozpowszechniony na całym świecie sposób organizacji przestrzeni uczelni wyższych. Rozwiązanie to było w różnych okresach rozwijane, a następni adaptowane w państwach i ośrodkach o odmiennych tradycjach akademickich Wraz z postępującą demokratyzacją dostępu do studiów wyższych, w szczególności po II wojnie światowej, tworzono w duchu modernizmu podmiejskie kampusy dla nowo zakładanych uniwersytetów, a także dla starszych uczelni, których historyczne budynki, zwykle rozproszone w śródmieściach, nie spełniały wymagań, jakie stawiano nowoczesnym placówkom edukacyjnym i naukowym (Gumprecht 2007; Coulson i in. 2015).

Za kontynuację tego procesu należy uznać zintensyfikowane powstawanie nowych kampusów polskich uczelni wyższych w pierwszych dwóch dekadach XXI w., kiedy to rosnace aspiracje edukacyjne młodych ludzi, korzystna sytuacja demograficzna oraz potrzeby rozbudowy niedoinwestowanej wcześniej infrastruktury badawczej i dydaktycznej połączyły się z możliwościami ich dofinansowania ze środków europejskich. Wiele z tych realizacji spotkało się z krytyką ze strony architektów i urbanistów (Kapecki 2015; Żabicki 2016). Podczas ich budowy w większym stopniu skupiano się na wznoszeniu kubatur w celu zaspokajania potrzeb lokalowych poszczególnych wydziałów i uczelni. Rzadko natomiast powstawały przestrzenie otwarte i budynki o mieszanych funkcjach, których celem byłaby integracja członków społecznośc akademickiej i pozaakademickiej, co wynikało zwykle z ograniczeń narzucanych przez instytucje finansujące, a także zastanej struktury organizacyjnej uczelni. Priorytetem było również konstruowanie wokół powstających obiektów uczelni układów komunikacyjnych zorientowanych na samochód, nierzadko w oderwaniu od już zrealizowanych oraz planowanych etapów w przypadku inwestycji wieloeta- powych. Pomimo odwoływania się do zachodnich wzorców w zakresie urbanistyk kampusów, ignorowano w trakcie ich realizacji najnowsze trendy rozwijania układów przestrzennych z różnorodnymi pod względem formy budynkami o wielofunkcyjnym charakterze, skupionymi wokół przestrzeni publicznych. Podobne zarzuty kierowane są do założeń kampusowych w innych krajach o semiperyferyjnym położeniu, np. w Turcji (Aydin, Ter 2008). Stanowią one bowiem późne realizacje przebrzmiałych już modernistycznych wzorców budowy miast strefowanych funkcjonalnie. W Polsce nie wdrażano również idei „megakampusów” - jednobryłowych, hybrydowych, wielowydziałowych budynków zintegrowanych na powrót z tkanką śódmiejską, służących nie tylko studentom i naukowcom, ale także mieszkańcom miast. Stwierdzono również, że w powstających kompleksach w znikomym stopniu wprowadzano w życie zasady zrównoważonego rozwoju (Kapecki 2015; Gyurkovich 2016; Żabicki 2016). Bolączką wielu publicznych realizacji architektonicznych i urbanistycznych w Polsce jest brak oceny ich funkcjonowania po oddaniu do użytku. Potęguje to wcześniejsze zaniedbania wynikające $\mathrm{z}$ braku partycypacyjnego podejścia przy ich projektowaniu (zob. Winnicka-Jasłowska 2015). Dotyczy to również kampusów, przy których powstawaniu pomijany był głos znacznej grupy ich przyszłych użytkowników. Doświadczenia zagraniczne pokazują, że w tego rodzaju kompleksach uniwersyteckich dokonuje się oceny sposobów użytkowania głównie wnętrz budynków, a rzadko otwartych przestrzeni między nimi, mimo „ich krytyczne roli w procesie nauczania i dla życia wspólnotowego" (Göçer i in. 2018: 126).

Skłoniło to autorów i autorki niniejszego tekstu do podjęcia się oceny jakości przestrzeni publicznych w obrębie Kampusu 600-lecia Odnowienia Uniwersytetu Jagiellońskiego w Krakowie, z którym to większość z nich jest związana z racji studiów i pracy. Nie sposób bowiem nie zgodzić się ze stwierdzeniem, iż „zaskakujące jest, że naukowcy wiedzą niewiele na temat środowiska, w którym oni i ich studenci spędzają tak dużo czasu" (Speake i in. 2013: 21; por. Cox i in. 2020). Analizowany kompleks budynków uniwersyteckich wraz z otaczającymi je przestrzeniami stanowi typowy przykład adaptacji idei kampusu uniwersyteckiego w krajach postsocjalistycznych Europy Środkowo-Wschodniej na początku XXI w., który powstał na obrzeżach miasta, na terenach wcześniej niezagospodarowanych (zob. Franaszek 2020). Przeprowadzone badania stanowią element szerszych działań prowadzonych przez autorki i autorów w ramach oddolnej inicjatywy Kampus $+{ }^{1}$, realizowanej przez interdyscyplinarny zespół studentów, doktorantów i pracowników Uniwersytetu Jagiellońskiego, której celem jest refleksja nad funkcjonowaniem kampusów uniwersyteckich z perspektywy ich użytkowników. Dlatego też w ramach niniejszego tekstu autorzy pragną w nowatorski sposób połączyć opinie osób korzystających z badanej przestrzeni z głosami ekspertek i ekspertów (z i spoza kampusu) z zakresu

https://www.facebook.com/kampusplusplus/ (dostęp: 15.05.2020). 
planowania przestrzennego, architektury i urbanistyki oraz aktywistek i aktywistów działających na rzecz poprawy sytuacji na kampusie.

Autorzy niniejszego artykułu stawiają sobie dwa cele: poznawczy, czyli ocenę jakości przestrzeni publicznych Kampusu UJ, oraz metodyczny - określenie silnych i słabych stron techniki crowdsensingu z użyciem aplikacji mobilnej do pozyskania informacji przestrzennej od osób studiujących w badanej przestrzeni. W swoim podejściu autorzy wpisują się w postulat prowadzenia badań przestrzeni publicznych ujmujących w sposób syntetyczny ich wymiar funkcjonalno-przestrzenny oraz zachodzące w nich zjawiska i procesy społeczno-ekonomiczne. Pojmują przy tym przestrzenie publiczne, podobnie jak inni badacze i badaczki, jako ogólnodostępne obszary, które dają możliwość wchodzenia w różnorakie interakcje społeczne, dzięki czemu stanowić mogą składową tożsamości terytorialnej (Kulawiak, Szmytkowska 2018). Odpowiednio uformowane przestrzenie publiczne mają dla mieszkańców znaczenie użytkowe, interakcyjne, obywatelskie i polityczne, aksjologiczne, symboliczne i tożsamościowe (Bierwiaczonek 2018).

\section{Znaczenie przestrzeni publicznych na kampusach uniwersyteckich}

W literaturze przedmiotu zwraca się uwagę na charakter kampusów jako pełnowartościowych jednostek osadniczych, które pełnić powinny podstawowe funkcje (oprócz edukacji i pracy również zamieszkania, usług, transportu, rekreacji itp.) dla z reguły kilku-, kilkunastotysięcznej populacji skupiającej się na relatywnie niewielkim obszarze (Winnicka-Jasłowska 2012; Bryx 2013; Coulson i in. 2015; Domae 2017; Göçer i in. 2018). Struktury przestrzenne historycznych kampusów, niekiedy odizolowanych od reszty świata mikrokosmosów, odzwierciedlać miały ideały wspólnoty akademickiej, sprzyjać wzmacnianiu więzi między jej członkami oraz wymianie wiedzy i doświadczeń między nimi (Gumprecht 2007; Coulson i in. 2015). Również współcześnie mówi się o planowaniu kampusów jako kompleksów budynków w ludzkiej skali, zorientowanych na pieszych, z miejscami i funkcjam umożliwiającymi kontakty międzyludzkie i partycypację społeczną (Domae 2017). Nic dziwnego zatem, że przestrzenie publiczne uznawane są za istotny element ich układu przestrzennego (Abu-Ghazzeh 1999) i dostrzega się ich kluczową, spajającą rolę w tkance miejskiej (Bierwiaczonek i in. 2012; Kulawiak, Szmytkowska 2018; Whyte 2018). W ostatnich latach, zarówno w dyskusjach naukowych, jak i przy praktycznych realizacjach, można mówić o znaczącym dowartościowaniu w architekturze i urbanistyce kampusów roli przypisywanej przestrzeniom publicznym (zarówno między budynkami, jak i wewnątrz nich), które stają się wręcz ich centralnym aspektem. Podkreśla się ich rolę również w kontekście otwierania się kampusów oraz społeczności akademickich na otoczenie i mieszkańców z sąsiedztwa (Maurrasse 2001; Kapecki 2015; Göçer i in. 2018; Sikorski i in. 2020). W mniejszych ośrodkach akademickich kampusy uczelni mogą stanowić jeden z centralnych punktów życia społeczności miejskich (Gumprecht 2007). W praktyce okazuje się, że nie wszystkie te idee są wdrażane z powodzeniem, a powstające kompleksy uniwersyteckie nie zawsze zaspokajają potrzeby i spełniają oczekiwania ich użytkowników w zakresie jakości przestrzeni publicznych (Aydin, Ter 2008; Salama 2008; Winnicka-Jasłowska 2008; Ozbil i in. 2018).

U podstaw pojmowania kluczowej roli przestrzeni publicznych w funkcjonowaniu kampusów jako struktury przestrzennej oraz uczelni jako organizacji tkwi kilka argumentów, które stanowią punkt wyjścia do badań przedstawionych w niniejszym tekście. Wynikają one z uniwersalnych potrzeb ludzi, którzy w krajobrazie miejskim z jednej strony poszukują miejsc umożliwiających im wchodzenie w interakcje społeczne, angażowanie się w działania społeczności i budowanie tożsamości lokalnej, a $\mathrm{z}$ drugiej strony pragną, by przestrzenie te zapewniały im kontakt z przyrodą doświadczenia estetyczne oraz możliwość odpoczynku i rekreacji (Matsuoka, Kaplan 2008). Na ludzkie doświadczanie przestrzeni wpływają zarówno elementy materialne (ukształtowanie przestrzeni pozytywowych i negatywowych), jak i niematerialne (aktywności w nich zachodzące) (Lucas, Romice 2008; Alexander i in. 2008; Speake i in. 2013; Göçer i in. 2018). W koncepcji przestrzeni pozytywowych i negatywowych, wywodzącej się z planu Rzymu Giambattisty Nollego z 1748 r., plany i kubatury budynków (przestrzeni pozytywowych) nadają kształt oraz trójwymiarową definicję przestrzeniom otwartym (negatywowym), stanowiąc ich dopełnienie. Dostrzec tę ścisłą zależność pomaga odwrócenie (w myślach) relacji formy i tła, tj. budynków oraz przestrzeni, która je otacza (Źórawski 2018).

Wiele rozważań teoretycznych i empirycznych pokazuje, że sposób zorganizowania przestrzeni ma bezpośredni wpływ na interakcje społeczne (Gehl 2009), a w rezultacie na wytwarzanie wiedzy (Jacobs 1969, 2000). O ile przekazywanie wiedzy o charakterze skodyfikowanym (codified knowledge) może stosunkowo łatwo odbywać się w sposób zapośredniczony, o tyle wyłanianie się nowych idei i dzielenie się wiedzą jeszcze nieustrukturyzowaną (tacit knoweledge) wymaga w większym stopni kontaktu bezpośredniego i organizacji przestrzeni sprzyjającej spotkaniom (Bathelt i in. 2004). Stąd też w koncepcjach miasta kreatywnego podkreśla się rolę przestrzeni w tworzeniu warunków do rozwoju komunikacji międzyludzkiej i kreatywnego myślenia (Brzozowska 2014). „Środowiskiem [kreatywnym] może być określony budynek, ulica, okolica a ostatecznie - całe miasto” (Landry 2013: 37). Kreatywność będzie kiełkować tam, gdzie odpowiednio uformowana przestrzeń sprzyja nieformalnej komunikacji, w miejscach, w których ludzie mogą się spotykać, wymieniać pomysłami, podtrzymywać istniejące kontakty i nawiązywać nowe, konfrontować z poglądami innych, sprzyjając generowaniu i przepływom idei (Domae 2017; Cox 
i in. 2020; Sikorski i in. 2020). Badacze kampusów powołują się w tym kontekście na rozważania duńskiego urbanisty Jana Gehla (2009), który postuluje tworzenie wysokiej jakości przestrzeni, umożliwiających realizację nie tylko czynności koniecznych (np. przejścia z budynku do budynku, z budynku na przystanek), ale również czynności opcjonalnych (np. spacerów, zatrzymywania się, przysiadania, obserwowania) Mogą one bowiem być zaczątkiem interakcji społecznych, a w kontekście uczelni owocować interdyscyplinarną współpracą (por. Göçer i in. 2018).

W tym aspekcie światowym trendem w kształtowaniu budynków uniwersyteckich jest tzw. krajobraz naukowy (learning landscape) (Cox i in. 2020). Jak pisze T. Kapecki (2015: 185): „Celem tej idei jest łączenie funkcji w taki sposób, aby obiekt sprzyjał nauce w każdym miejscu, w szczególności samokształceniu i uczeniu poziomemu - wzajemnie od użytkowników. Projektuje się tak, aby maksymalnie ułatwić, a nawet sprowokować sytuacje komunikacyjne i kontaktu społecznego między użytkownikami”.

W konsekwencji w najbardziej nowatorskich realizacjach budynków akademickich podkreśla się przede wszystkim zalety przestrzeni wspólnej jako najciekawsze i najbardziej spektakularnej. Krajobraz naukowy nie ogranicza się do wnętrz budynków, ale wychodzi poza ich mury w przestrzeń między nimi, sprzyjając interakcjom społecznym i wzajemnemu uczeniu się, a w konsekwencji budowaniu kompetencji społecznych, rozwojowi osobistemu i zawodowemu studentek i studentów oraz pracownic i pracowników.

„Ludzie chcą gromadzić się, wchodzić w interakcje społeczne, uczyć się i wyrażać swoją kreatywność w wygodnych i zapraszających przestrzeniach, które zapewniają cień i schronienie, miejsca do siedzenia, jedzenia i picia oraz w których mogą cieszyc się aktywnościami artystycznymi i kulturalnymi” (O’Rourke, Baldwin 2016: 114).

Poprzez odpowiednie uformowanie przestrzeń może sprzyjać interakcjom społecznym i komunikacji międzyludzkiej (sociopetal space), a w przeciwnym wypadku ograniczać je (sociofugal space) (Osmond 1957; Sommer 1967). Wynikać to może np. z zaprojektowania miejsc siedzących (zwróconych do siebie lub odwróconych od siebie, możliwych do przestawienia lub umocowanych na stałe), ich wyglądu, estetyki i materiałów, z których zostały wykonane.

Odpowiednio ukształtowane, zróżnicowane przestrzenie publiczne kampusu zapewniają możliwość zarówno podejmowania aktywności w grupach, jak i wyciszenia się oraz relaksacji. Dzięki temu podnoszą jakość życia osób spędzających na nim czas, bez względu na to, czy przebywają tam dłużej z racji studiowania i pracy, czy krócej, np. mając czas wolny, odwiedzając uczelnię w trakcie wydarzeń przez nią organizowanych (Biddulph 1999; Aydin, Ter 2008; McFarland i in. 2008; Speake i in. 2013; Liprini, Coetzee 2017; Göçer i in. 2018; por. Kulawiak, Szmytkowska 2018). Otwarte przestrzenie, w tym tereny zielone o zróżnicowanym charakterze, moga korzystnie oddziaływać na dobrostan psychiczny osób przebywających na kampusie, rozładować stres i przeciążenie związane z funkcjonowaniem w środowisku akademickim oraz w dużych zbiorowościach ludzkich, przyczyniając się do mentalnej odbudowy. Natomiast przestrzenie sprzyjające kontaktom społecznym dają szansę na zredukowanie poczucia samotności, zwłaszcza wśród najmłodszych roczników studentów (Griffith 1994; Aydin, Ter 2008; Speake i in. 2013; Seitz i in. 2014; Siu Yu Lau i in. 2014; Liprini, Coetzee 2017; Cox i in. 2020). Klasyczne badania z zakresu psychologii środowiskowej pokazują, że użytkownicy przestrzeni pozytywnie postrzegają obszary, które cechują się jednocześnie spójnością i złożonością, czytelnością i tajemniczością (Kaplan 1987; Kaplan i in. 1998; Han 2007). Tylko wtedy przyciągają i zatrzymują ludzi, umożliwiając im regenerację. W przeciwnym razie odpychają, stanowiąc przestrzeń realizacji czynności jedynie o charakterze koniecznym. Miejsca sprzyjające psychicznemu odpoczynkowi zapewniają poczucie bezpieczeństwa prywatność, możliwość siedzenia i widok na zieleń, natomiast miejsca zachęcające do kontaktów społecznych przyciągają większe grupy ludzi dzięki dodatkowym funkcjom, np. punktom gastronomicznym (Spooner 2014).

W konsekwencji jakość otwartych przestrzeni publicznych kampusu, w tym terenów zielonych, stanowi - obok poziomu prowadzonych badań i edukacji - ważn element konkurencyjności najlepszych zagranicznych uczelni (Griffith 1994; Gumprecht 2007; McFarland i in. 2008; Speake i in. 2013; Coulson i in. 2015; Domae 2017; Cox i in. 2020; Sikorski i in. 2020). Stanowią one bowiem wizytówkę uczelni, reprezentując wartości uznawane przez społeczność akademicką. Dzięki temu mogą one być jednym z czynników przyciągających kandydatów na studia, a następnie pozostawać na dłużej w pamięci absolwentów. Od ich wyglądu, dostępności i funkcjonalności zależy, czy będą to dobre czy złe wspomnienia. Przyjazne przestrzenie publiczne mogą być także istotnym elementem konkurowania o najwyższej klasy badaczki i badaczy, którzy chcą pracować w miejscu oferującym coś więcej niż tylko najlepsze sale wykładowe i laboratoria badawcze. Takie rozwiązania wdrażają m.in amerykańskie uczelnie wyższe, które przekształcają parkingi w centralnych częściach swoich kampusów w pełnowartościowe przestrzenie publiczne, w których można spędzać czas w przerwie między zajęciami lub prowadzeniem badań. Na konkurencyjnym rynku akademickim przewagę zyskują uczelnie, które na swoich kampusach zapewniają estetyczną i bezpieczną przestrzeń pełną życia. Poprawa jakości przestrzeni publicznych oraz nasycenie ich znaczeniami może sprzyjać budowaniu i wzmacnianiu tożsamości społeczności akademickiej (O’Rourke, Baldwin 2016 Domae 2017; por. Kulawiak, Szmytkowska 2018).

Atrakcyjnie ukształtowana otwarta przestrzeń o charakterze formalnym lub siedliska zachowane w formie naturalnej (...) ułatwiają budowanie dostojnego wizerunku kampusu, wzmacniają poczucie przywiązania wśród absolwentów, budują silne poczucie wspólnoty, ograniczają niekorzystne odczucia wynikające z gęstości zabudowy kampusu" (Griffith 1994: 648). 
Przestrzenie kampusu mają również znaczenie w budowaniu obrazu uczelni wśród mieszkańców miasta, zwłaszcza z najbliższego sąsiedztwa, jako instytucji otwartej i zapraszającej lub zamkniętej i zorientowanej na siebie. Tym samym kampus może być rzeczywistym odzwierciedleniem realizacji trzeciej misji uczelni przez budowanie relacji z otoczeniem i podejmowanie odpowiedzialności wobec społeczności lokalnej i regionalnej (por. Sikorski i in. 2020). Jak stwierdza Marek Bryx (2013), współczesna przestrzeń uniwersytecka łączy wspólnotę akademicką z resztą społeczeństwa. Uczelnia ma być miejscem, gdzie kreowane i wzmacniane są interakcje pomiędzy sferą nauki a gospodarką i społeczeństwem. Implikuje to powstawanie kampusów, które powinny uwzględniać odpowiedzialność uniwersytetu w sferze ekonomicznej, społecznej i ekologicznej (Live Baltic Campus... 2017). Teza ta nabiera szczególnego wymiaru wobec aktualnej katastrofy klimatycznej. Jeśli kampus ma odgrywać rolę miejsca demonstrowania dobrych praktyk i testowania nowych rozwiązań dotyczących kształtowania przestrzeni, to powinien być nasycony inteligentnymi rozwiązaniami i technologiami w różnorakich sferach: zarządzania energią transportem, środowiskiem, relacjami społecznymi itp. Przestrzeń kampusu stanowic może laboratorium przyszłych rozwiązań, odzwierciedlać wyniki prowadzonych tam badań oraz treści edukacyjne przekazywane wewnątrz budynków. Powinna być przy tym przestrzenią uczącą i uczącą się, otwartą na eksperymenty (por. Whyte 2018), adaptującą się do współczesnych wyzwań kształtowania przestrzeni miejskiej w dobie zmian klimatu i środowiska.

Podsumowując, współczesny modelowy kampus uniwersytecki powinien cechować się wielofunkcyjnością i zróżnicowaniem przestrzeni zgodnie z zasadami zrównoważonego rozwoju i różnorodności biologicznej. Teren kampusu powinien dla różnych kategorii użytkowników pełnić, obok miejsca zamieszkania i pracy, funkcję „trzeciego miejsca” (Oldenburg 1999), w którym mogą w sposób niezobowiązujący spędzać czas wolny. Powinno się dążyć do stworzenia przestrzeni sprzyjającej budowaniu wspólnoty, działaniom społecznym, kulturalnym, sportowym, animowaniu współpracy, stymulowaniu kontaktów i komunikacji nieformalnej jako niezbędnego warunku wyzwalania kreatywności. Przestrzeń kampusu powinna służyć wymianie doświadczeń, eksperymentowaniu i podejmowaniu działań tymczasowych, dawać możliwość współdecydowania o jej kształcie i funkcjach. Powinna być otwarta na sąsiedztwo oraz potrzeby różnych grup użytkowników (np. osób niepełnosprawnych) (por. Live Baltic Campus... 2017).

W tym kontekście uderzają tendencje obserwowane w polskich warunkach, gdzie ogromny potencjał i znaczenie przestrzeni publicznej kampusów są niedoceniane. Swoistym paradoksem jest to, że wykładane w budynkach kampusowych najnowsze koncepcje i dobre praktyki z zakresu planowania oraz zagospodarowania przestrzennego zderzają się boleśnie $\mathrm{z}$ faktycznym funkcjonowaniem przestrzeni publicznych w ich bezpośrednim otoczeniu. Dopiero w ostatnich latach (a są to raczej pojedyncze przypadki) można mówić o powolnej zmianie myślenia, czego przykładem są działania podejmowane przez m.in. Uniwersytet Warszawski (budżet partycypacyjny, powołanie Biura Innowacji w Przestrzeni Akademickiej), Uniwersytet Śląski (deklaracja kampusowa o zrównoważonym rozwoju, wpisanie kampusu w strategię rewitalizacji zdegradowanej przestrzeni śródmieścia z nagradzanymi realizacjami architektonicznymi Wydziału Radia i Telewizji oraz międzyuczelnianej biblioteki CINIBA) i Uniwersytet Jagielloński (zainicjowany oddolnie konkurs na zagospodarowanie części terenu Kampusu UJ, uwzględniający tereny zieleni rekreacyjnej i biocenotycznej, łączący funkcje architektury ogrodowej, ogrodu naukowo-dydaktycznego, rekreacji tradycyjnej i kontemplacyjnej oraz wzmacniania więzi i relacji społeczności akademickiej).

Źródłami niekorzystnych tendencji urbanistycznych w polskich kampusach sa zdaniem Piotra Żabickiego (2016), m.in.: kryzys polityki przestrzennej i prymat doktryny liberalnej w planowaniu przestrzennym oraz polityce miejskiej; brak planów miejscowych i brak właściwej koordynacji planów inwestycyjnych uczeln oraz miast; brak świadomości urbanistycznej decydentów (uczelnianych i miejskich) prowadzący do niekonsekwentnie realizowanych strategii przestrzennych polskich uczelni; wadliwe prawo, które prowadzi do marnotrawienia publicznych pieniędzy na budowle nierealizujące publicznego interesu. Generalnie trudno nie zgodzic się z jego tezą (Żabicki 2016: 139), że w polskich warunkach mamy do czynienia $\mathrm{z}$ „marginalizacją przez kolejne władze polityczne, samorządowe i uczelniane spraw polityki przestrzennej i urbanistyki”. Szczególną bolączką jest także problem strukturalny - zanik umiejętności kształtowania przestrzeni (kompetencji urbanistycznych) oraz brak partycypacyjnego modelu planowania kampusów (kwestia ta podnoszona jest również przez badaczy z innych krajów - por. O’Rourke, Baldwin 2016; Göçer i in. 2018). Paradoksem jest zupełny (w większości przypadków) brak współdecydowania użytkowników tej przestrzeni, w tym niejednokrotnie wysokiej klasy profesjonalistów (np. z zakresu urbanistyki, ochrony środowiska, architektury krajobrazu, zarządzania przestrzenią) zatrudnionych na uczelniach. Wynika to z faktu, że za inwestycje i zarządzanie kampusem odpowiedzialne są piony kanclerskie, które nie mają odpowiedniego rozeznania w zakresie potrzeb i oczekiwań społecznośc kademickiej. Poza tym u wielu decydentów brak świadomości znaczenia wysokiej jakości przestrzeni publicznej, co przy ciągle jeszcze słabej presji interesariuszy na wprowadzanie zmian skutkuje niedostosowaniem kompleksów kampusowych do potrzeb dużego grona ich użytkowników.

\section{Charakterystyka obszaru badań}

Tereny położone w pobliżu Pychowic, w południowo-zachodniej części Krakowa, w odległości około $4 \mathrm{~km}$ od centrum miasta zostały po raz pierwszy przeznaczone 
pod działalność naukową w planie miejscowym uchwalonym w 1988 r. (Jędrychowski 2007; Böhm 2008). Rozległy, niezabudowany teren o powierzchni ponad 135 ha zajęły później Uniwersytet Jagielloński, Papieska Akademia Teologiczna (obecnie Uniwersytet Papieski im. Jana Pawła II), Polska Akademia Nauk oraz Krakowski Park Technologiczny. Uniwersytetowi Jagiellońskiemu przypadła blisko połowa całego obszaru, położona najbliżej centrum miasta, na której w latach 1998-2017 zrealizowano Kampus 600-lecia Odnowienia Uniwersytetu Jagiellońskiego, zwany powszechnie III Kampusem UJ, który stanowi przedmiot analiz w niniejszym tekście (ryc. 1). Powstało wówczas dziesięć budynków mieszczących siedziby instytutów i wydziałów, oraz jednostek międzywydziałowych, głównie nauk ścisłych i przyrodniczych. Na terenie uniwersyteckim planowana jest ponadto budowa obiektów sportowych oraz domów studenckich. Na gruntach należących do pozostałych instytucji do 2019 r. zrealizowano m.in. bibliotekę UPJPII, laboratoria badawcze Jagiellońskiego Centrum Innowacji, siedzibę Krakowskiego Parku Technologicznego, obiekty biurowe firm z sektora IT (m.in. Nokia, Ericsson i Motorola Solutions) i outsourcingowego (m.in. Shell Energy Campus). Kompleksy zabudowy uniwersyteckiej i parku technologicznego skupiają się w dwóch, dośc odległych od siebie i dotąd niepowiązanych częściach terenu. Cały obszar graniczy od północy z Bielańsko-Tynieckim Parkiem Krajobrazowym i jego otuliną, które nie są przewidziane pod zabudowę. Po południowej stronie terenu UJ znajduje się natomiast wielkopłytowe osiedle mieszkaniowe, powstałe na przełomie lat 80. i 90 XX w., rozbudowujące się wciąż żywiołowo w kierunku południowo-zachodnim.

Jak stwierdza Aleksander Böhm (2008), autor koncepcji zagospodarowania całego terenu kampusu, sposób urządzenia tego zasadniczo niezabudowanego wcześnie obszaru stanowił kompromis między przeciwstawnymi dążeniami, zapisanymi w obowiązującym wówczas (1994) planie ogólnym zagospodarowania: uwarunkowaniami krajobrazowymi z obowiązkiem ochrony krajobrazu otwartego oraz oczekiwaną dla tego obszaru wysoką intensywnością zabudowy. Zgodnie z wymaganiami planu inwestycję poprzedziło opracowanie koncepcji zagospodarowania terenu w postaci planu koordynacyjnego ${ }^{2}$, dla którego przygotowano wcześnie studium krajobrazowe ${ }^{3}$. Zidentyfikowano wówczas wartościowe budynki i zespoły zabudowy monumentalnej widoczne na horyzoncie z terenu przyszłego kampusu. Układ głównych przestrzeni publicznych kampusu i parku technologicznego (ulic, alei i placów) podporządkowano kierunkom otwarć widokowych na te obiekty, a wyznaczone przez nie kwartały przeznaczono pod zabudowę. Główną osią

2 Plan koordynacyjny dla III Kampusu UJ wraz z Parkiem Technologicznym opracował w 1998 r. zespó pracowników Instytutu Architektury Krajobrazu i Centrum Komputerowego Politechniki Krakowskiej pod kierunkiem prof. Aleksandra Böhma.

Studium krajobrazowe dla III Kampusu UJ opracowat w 1997 r. zespół autorski: Aleksander Böhm, Krzysztof Bieda, Agata Zachariasz.

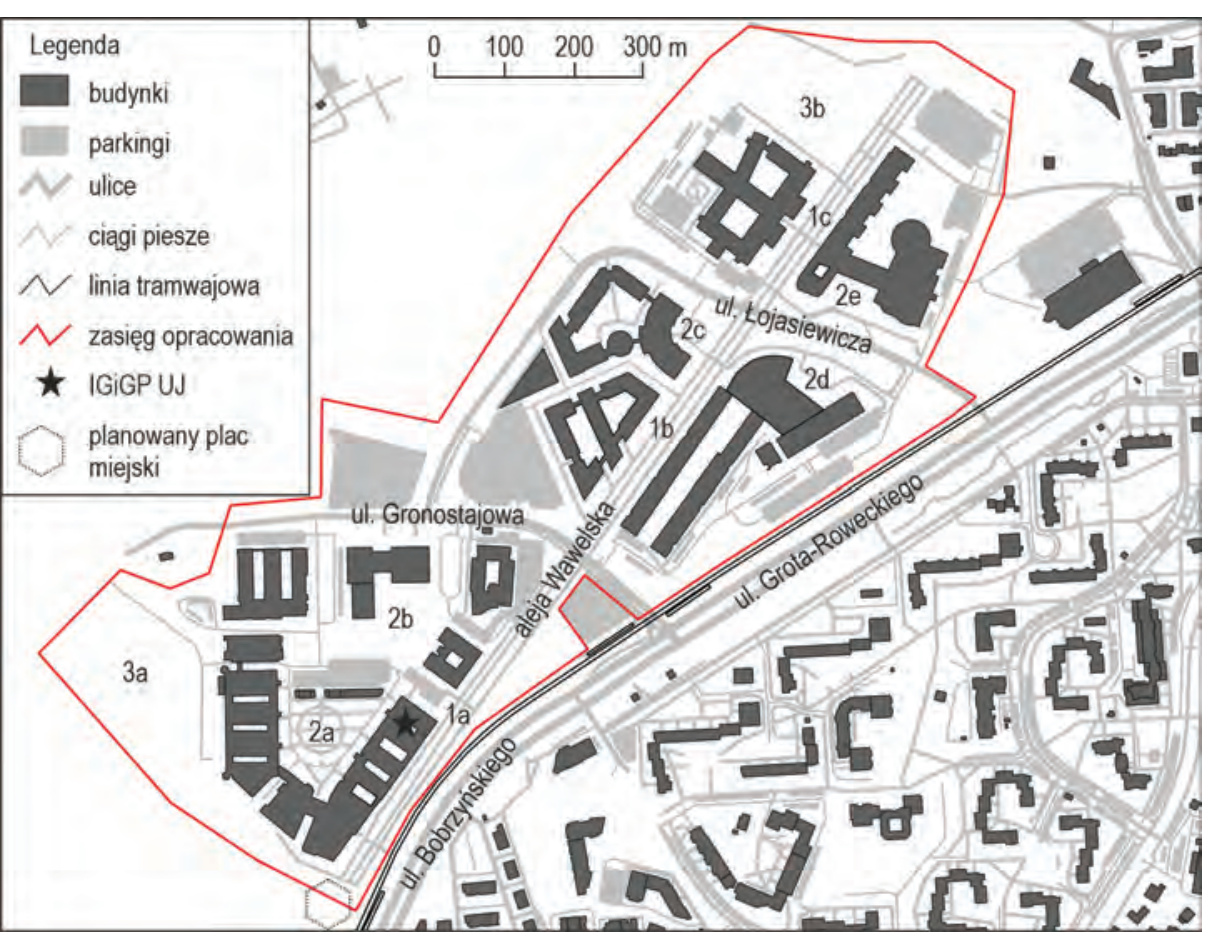

Ryc. 1. Główne elementy struktury przestrzennej III Kampusu UJ

Fig. 1. Main elements of the Third Campus of the Jagiellonian University

Objaśnienia: symbolami oznaczono analizowane przestrzenie publiczne: 1a) południowy, 1b) srodkowy i 1c) północny odcinek alei Wawelskiej, 2a) dziedziniec Kompleksu Nauk Biologicznych, 2b) dziedziniec między Małopolskim Centrum Biotechnologii, Centrum Edukacji Przyrodniczej i Instytutem Nauk Geologicznych, 2c) plac przed Wydziałem Fizyki, Astronomii i Informatyki Stosowanej, 2d) plac przed Wydziałem Chemii, 2e) plac przed Wydziałem Zarządzania i Komunikacji Społecznej, 3a) teren zielon za Wydziałem Biochemii, Biofizyki i Biotechnologii, 3b) park za Wydziałem Matematyki i Informatyk IGiGP UJ - Instytut Geografii i Gospodarki Przestrzennej Uniwersytetu Jagiellońskiego - miejsce, w którym studiowali uczestnicy badania.

Explanations: public spaces under study marked with symbols: 1a) southern, 1b) central and 1c) northern part of the Wawel Avenue, 2a) courtyard of the Biological Science Complex, 2b) courtyard between the Małopolska Centre of Biotechnology, the Nature Education Centre and the Institute of Geologica Sciences, 2c) square in front of the Faculty of Physics, Astronomy and Applied Computer Science, 2d) square in front of the Faculty of Chemistry, 2e) square in front of the Faculty of Management an Social Communication, 3a) green area behind the Faculty of Biochemistry, Biophysics and Biotechnol(a) 3 b) oreen area behind the Faculty of Mathematics and Computer Science; IGiGP UJ - Institute of Geography and Spatial Management - place of study of the survey participants. 
założenia stała się pieszo-rowerowa aleja Wawelska, wyznaczona między planowanym placem na skraju kampusu UJ a otwarciem widokowym na Wawel. Aleja ma formę długiego na blisko $1 \mathrm{~km}$ i szerokiego na około $40 \mathrm{~m}$ (pomiędzy przeciwległymi pierzejami) ciągu, rozciętego dwiema ulicami dojazdowymi - Gronostajową i Łojasiewicza. Plan koordynacyjny służył organizacji postępowań przetargowych na zabudowę poszczególnych kwartałów oraz wydawaniu pozwoleń na budowę. Po utracie ważności ogólnych planów zagospodarowania przestrzennego z końcem 2003 r. ustalenia planu koordynacyjnego znalazły kontynuację w uchwalonym w roku 2005 miejscowym planie zagospodarowania przestrzennego „III Kampus UJ Wschód" i jego aktualizacji w 2013 r.

W pierwszym etapie budowy powstał rozległy Kompleks Nauk Biologicznych (KNB), który składa się z dwóch skrzydeł oraz centralnie położonego zwornika (m.in. $\mathrm{z}$ aulą, biblioteką, kafeterią i drobnymi usługami). W pierwotnym zamierzeniu miał on pełnić funkcję głównego wejścia na teren kampusu, którego nie udało się zrealizować, gdyż nie powstał przewidziany w planie koordynacyjnym plac miejski. Nie jest również wykorzystywany potencjał zrealizowanego w tej częśc tarasu ze schodami, mimo że działa tam kawiarnia. Kompleks ten wraz z pięcioma mniejszymi budynkami tworzy zwartą kompozycję skupioną wokół nieregularnego dziedzińca, który autor tego założenia, architekt Marian Fikus, określił mianem „plateau widokowego z ogrodem” (Fikus 2002: 17). Zwrócone są do niego wejścia do budynków, co sprawia, że to wnętrze urbanistyczne ma szansę funkcjonować jako lokalne centrum tej cześci kampusu. Jest ono jednak słabo i przypadkowo (przez parking i drogi manewrowe) powiązane z aleją Wawelską. Budynki pozostałych czterech wydziałów (każdy z własną biblioteką) mają bardziej rozczłonkowane rzuty, o jednym lub wielu wewnętrznych dziedzińcach. Każdy z nich stanowi samodzielną, funkcjonalnie samowystarczalną kompozycję o skomplikowanej geometrii i urozmaiconych, rytmicznych fasadach, a ich cechą wspólną jest konsekwentnie prowadzona linia zabudowy wzdłuż alei Wawelskiej. Zwrócone są do niej jednak wejścia główne tylko do dwóch budynków, a poza nimi fasady w strefie parteru otwierają się jedynie wyjściami ewakuacyjnymi. Pod względem języka architektonicznego obiekty III Kampusu UJ wymieniane są jako przykłady współczesnej polskiej architektury akademickiej pozbawionej cech (Kapecki 2015: 67): „część powstałych rozwiązan nie podbija serc miłośników architektury”, a „poziom realizacji okazał się różny”.

Obsługę komunikacyjną kampusu i parku technologicznego zapewnia ciąg ulic Grota Roweckiego i Bobrzyńskiego, biegnących wzdłuż południowej krawędz obszaru. W wyniku ukończonej w 2012 r. rozbudowy te ulice klasy głównej ukształtowane zostały jako dwujezdniowe o co najmniej dwóch pasach ruchu w każdym kierunku, z wydzielonym torowiskiem tramwajowym i drogą dla rowerów po stronie kampusu oraz obustronnymi chodnikami. Szerokość w liniach rozgraniczających wynosi około $50 \mathrm{~m}$, co podkreślone jest ciągami wysokich na $6 \mathrm{~m}$ ekranów akustycz- nych (po stronie kampusu w pobliżu KNB). Na długości całego obszaru znajduje się pięć, dość odległych od siebie, przejść dla pieszych, z tego zaledwie trzy na długości kampusu uniwersyteckiego. W rezultacie wspomnianej rozbudowy ulica stanowi uciążliwą barierę urbanistyczną, przerywającą ciągłość tkanki miejskiej oraz utrudniająca powiązania funkcjonalne i przestrzenne kampusu z sąsiednimi terenami mieszkaniowymi. Kampus obsługiwany jest przez trzy przystanki tramwajowe, jednak ich lokalizacje nie zapewniają dogodnego dojścia do budynków uniwersytetu ani też jego głównej osi. Najkrótsza i chętnie wybierana trasa z przystanku położonego najbliższej centrum miasta do głównego generatora ruchu na terenie kampusu - położonego po stronie wschodniej gmachu największego pod względem liczby studentów Wydziału Zarządzania i Komunikacji Społecznej (blisko 7,5 tys. pod koniec 2017 r.) - prowadzi wzdłuż strefy dostaw i parkingu supermarketu do bocznego wejścia. Z kolei ani zespół budynków KNB, ani zachodni kraniec alei, wobec niezrealizowania placu miejskiego, nie są powiązane z trzecim (położonym najdalej od centrum miasta) przystankiem tramwajowym w sposób adekwatny do swojej rangi. Dojście z tego przystanku prowadzi wzdłuż wysokiej ściany ekranów akustycznych do bocznego wejścia do kompleksu. Podsumowując, należy stwierdzić, że nieuwzględnienie w wyrazistej kreacji urbanistycznej alei Wawelskiej dogodnych (najkrótszych) tras ruchu pieszego do przystanków tramwajowych sprawia, iż jej potencjał nie jest wykorzystany.

\section{Metody badawcze}

Badania przestrzeni publicznych w obrębie kampusów uniwersyteckich są stosunkowo nieliczne. Korzystają jednak z szeregu metod badawczych wykorzystywanych w ocenie tego rodzaju przestrzeni w miastach. Wśród nich przeważają dwie grupy ujęć badawczych: obejmujących z jednej strony ocenę ekspercką dzięki obserwacjom terenowym, kartowaniu behawioralnemu, dokumentacji fotograficznej, z drugiej strony - pozyskiwanie opinii użytkowników przez badania ankietowe, wywiady pogłębione, spacery badawcze, metody wizualne (fotografowanie przestrzeni przez respondentów) (por. przegląd stosowanych metod badawczych w Göçer i in. 2018).

$\mathrm{W}$ tradycyjnych badaniach ankietowych przestrzeni publicznych kampusów ich uczestnicy w trakcie wypełnienia kwestionariusza $\mathrm{z}$ reguły nie znajdują się w miejscach, które oceniają. W niniejszym tekście proponujemy nowatorskie podejście do badań ankietowych z wykorzystaniem aplikacji mobilnej, która umożliwia respondentom wielokrotne wypełnianie kwestionariusza w różnych punktach bezpośrednio na terenie kampusu. Przeprowadzona przez nas ocena jakości przestrzen publicznych kampusu na podstawie opinii ich użytkowników wpisuje się w nurt badań określanych angielskim terminem mobile crowdsensing lub mobile participatory 
sensing (Kanhere 2013; Aanensen i in. 2014; Kidyba, Makowski 2017). Polegaj one na generowaniu dużej liczby danych terenowych (np. odpowiedzi na pytania w ankiecie) i przesyłanie ich bezpośrednio przez osoby uczestniczące w badaniu za pomocą aplikacji mobilnych. Tego rodzaju podejście umożliwia angażowanie społeczności związanych z danym obszarem, które uczestnicząc w projektach crowdsensingowych, mogą dzielić się wiedzą lokalną, dającą się przekładać na podejmowanie decyzji. Mogą one być również inicjowane przez przedstawicieli tych społeczności. Crowdsensing $\mathrm{w}$ badaniach przestrzennych umożliwia zebranie mniejszym kosztem większej liczby danych od zaangażowanych uczestników projektu. Mogą one jednak napotykać trudności w rekrutacji uczestników, w tym pominięcie niektórych grup społecznych, ograniczenia techniczne, niekompletność danych z powodu wycofania się uczestników w trakcie badania, a niekiedy także ze złośliwego działania niektórych z nich, wpływającego na jakość danych (Burke i in. 2006; Kanhere 2013).

W badaniach wykorzystano platformę Epicollect5 (https://five.epicollect.net/), opracowaną i bezpłatnie udostępnianą przez Imperial College London. Umożliwia ona przygotowanie, zebranie i opracowanie terenowych badań ankietowych o charakterze crowdsensingowym. Jej zaletą jest nie tylko możliwość zbierania odpowiedz tekstowych, ale również pozyskanie materiału audiowizualnego (zdjęć, nagrań audio i wideo), powiązanego z konkretną lokalizacją geograficzną (Aanensen i in. 2014) Pierwotnie miała ona usprawnić zbieranie danych epidemiologicznych, ale wkrótce dostrzeżono jej potencjał w realizacji badań geograficznych (Bryant i in. 2013; France i in. 2015; Ahmed i in. 2019).

W badaniu udział wzięli studenci I roku Instytutu Geografii i Gospodarki Przestrzennej Uniwersytetu Jagiellońskiego pod koniec roku akademickiego (po 8 miesiącach studiowania na kampusie), którzy w trakcie ćwiczeń terenowych zostali poproszeni o ocenę różnych, wybranych przez siebie punktów na terenie kampusu, które są dostępne dla jego użytkowników bez ograniczeń (nie oceniali zatem wielu wewnętrznych dziedzińców z ograniczonym dostępem). Przemieszczali się indywidualnie w dogodnym dla siebie czasie, wypełniając w każdym z wybranych przez siebie punktów krótki kwestionariusz ankiety. Obejmował on cztery główne kwestie odnoszące się do najbliższego otoczenia, w którym się znajdowali (jednorodnej przestrzeni kilka, kilkanaście metrów dookoła danego miejsca): ocenę komfortu poruszania się i przebywania w danym miejscu z punktu widzenia pieszego (cztery pytania zamknięte), własne doświadczenie korzystania $\mathrm{z}$ danej przestrzeni (jedno pytanie zamknięte), obserwowane zachowania innych ludzi (dwa pytania zamknięte), elementy, które się podobają i nie podobają (dwa pytania otwarte z możliwością wykonania zdjęć). W każdym miejscu uczestnicy zapisywali w aplikacji współrzędne geograficzne badanego punktu. Łącznie w badaniu wzięło udział 60 studentów, którzy ocenil 960 punktów, spośród których, po odrzuceniu obserwacji o dokładności pomiaru lokalizacji poniżej akceptowanego zasięgu, w ostatecznej analizie uwzględniono
953 punkty. Uczestnicy wychodzili w teren w ciągu pięciu dni: 4, 5, 7, 11 i 12 czerwca 2018 r., które charakteryzowały się korzystną z punktu widzenia badan pogodą: temperatury w ciągu dnia między godz. 8 a 20 osiągały wartości minimalne od 16,4 do 22,4 stopni Celsjusza, a maksymalne od 21,1 do 27,4 stopni Celsjusza, bez deszczu, z niskim lub średnim zachmurzeniem.

Podstawą analiz przestrzennych w niniejszym artykule są informacje zebrane przez uczestników o innych użytkownikach przebywających w przestrzeni kampusu. Zastosowanie techniki crowdsensingowej umożliwiło zebranie dużej liczby obserwacji z dość rozległego terenu kampusu, co byłoby trudnym zadaniem dla pojedynczych badaczy. Dla każdego punktu i jego otoczenia uczestnicy badania obserwowali, czy w danej przestrzeni ktoś się znajdował. Jeśli tak, to odnotowywali, czy były to pojedyncze osoby (do 2-3 osób łącznie), kilka osób (4-9 osób) czy większa liczba osób (powyżej 10 osób). Następnie zaznaczali przeważający rodza obserwowanego zachowania w uproszczony sposób, tj. czy użytkownicy przestrzen „głównie przechodzili, bez zatrzymywania się”, czy „głównie siedzieli, stali, np. rozmawiali, spacerowali wolno". Mogli też wybrać odpowiedź pośrednią, stwierdzając, że „niektórzy przechodzili bez zatrzymywania się, a niektórzy siedzieli, stali, np. rozmawiali, spacerowali wolno".

W interpretacji wyników wykorzystano założenie, że obserwowane zachowania osób w przestrzeni są pochodną atrakcyjności danej przestrzeni dla pieszych, stąd też stanowić mogą wskaźnik jakości przestrzeni publicznej z punktu widzenia tej grupy użytkowników kampusu. Przyjęto, opierając się na propozycji Gehla (2009), że w „złej” przestrzeni, o niskiej atrakcyjności dla pieszych będą oni wykonywać głównie czynności konieczne, przechodząc bez zatrzymywania się, podczas gdy w „dobrej” przestrzeni częściej będą wykonywać czynności opcjonalne i społeczne zatrzymywać się, przysiadać, rozmawiać, nawiązywać i podtrzymywać kontakty społeczne. Dodatkowa analiza materiału wizualnego (fotografii wykonanych przez uczestników badania) wraz z osobistym komentarzem pozwoliła zrozumieć, dlaczego poszczególne przestrzenie publiczne mogą być uznawane za mniej lub bardzie atrakcyjne w oczach studentek i studentów. Uzyskane wyniki zostały skonfrontowane z oceną autorek i autorów tekstu poprzez odniesienie się zarówno do koncepcji Gehla, jak i do wiedzy eksperckiej oraz własnego doświadczenia w korzystaniu z przestrzeni kampusu.

Ze względu na to, że punkty, w których respondenci dokonywali oceny, były nierównomiernie rozmieszczone w przestrzeni, a także mając świadomość niedokładności pomiaru pozycji GPS w telefonach komórkowych, w celu stworzeni uśrednionego obrazu odpowiedzi respondentów dokonano ich agregacji (ryc. 2). Posłużono się regularną siatką punktów położonych co 12,5 m, wokół nich wyznaczono okręgi o promieniu 12,5 m, dla których z odpowiedzi respondentów obliczano wartości średnie, którym przyporządkowano umowne wartości liczbowe 


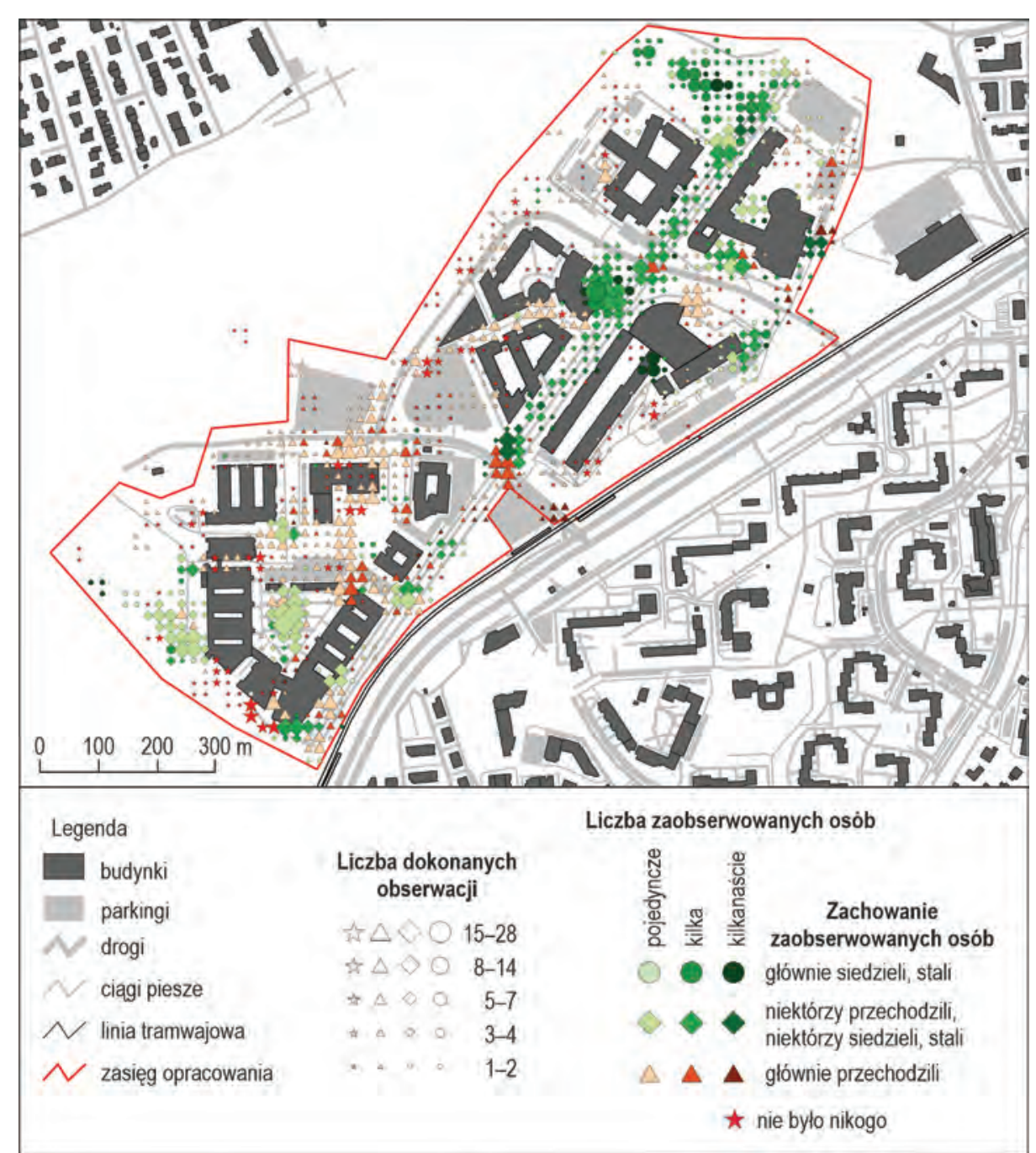

Ryc. 2. Zachowania użytkowników przestrzeni kampusu obserwowane przez uczestników badania crowdsensingowego

Fig. 2. Behaviour of the campus users as observed by the participants of the crowdsensing survey
(0 - brak osób w przestrzeni, 1 - pojedyncze osoby, 2 - kilka osób, 3 - większa liczba osób; 1 - głównie przemieszczanie się, 2 - zarówno przemieszczanie się, jak i zatrzymywanie się, 3 - głównie zatrzymywanie się). Tak stworzone okręgi zachodziły na siebie i część punktów była uwzględniana w więcej niż tylko jednym okręgu przyniosło to bardziej wygładzony obraz i pozwalało skupić się na prawidłowościach. Warto jednocześnie zwrócić uwagę na zróżnicowanie gęstości punktów w różnych częściach kampusu, która wynika często z ograniczonej dostępności niektórych przestrzeni dla pieszych (np. parkingi samochodowe). Niższą gęstość punktów obserwacji odnotowano jednak także w przestrzeniach publicznych przeznaczonych dla pieszych, co należy wziąć pod uwagę zarówno analizując jakość tych przestrzeni, jak i oceniając zastosowaną technikę zbierania danych. Choć w badaniu pozornie oparto się na bardzo prostym wskaźniku, to dzięki jego masowości przynosi on zaskakująco dużo informacji, które zostały skonfrontowane z obserwacjami i wiedzą ekspercką autorów tekstu.

Szczegółowej analizie poddano osiem wyraźnie wyodrębniających się w przestrzeni kampusu przestrzeni publicznych, które można podzielić na trzy kategorie (ryc. 1)

1) aleja Wawelska - główna aleja piesza w osi kampusu podzielona ulicami na trzy odcinki - południowy (1a), środkowy (1b) i północny (1c);

2) otwarte dziedzińce i place przed budynkami wydziałów: 2a) dziedziniec Kompleksu Nauk Biologicznych (KNB), 2b) dziedziniec między Małopolskim Centrum Biotechnologii (MCB), Centrum Edukacji Przyrodniczej (CEP) i Instytutem Nauk Geologicznych (ING), 2c) plac przed Wydziałem Fizyki, Astronomii i Informatyk Stosowanej (WFAiIS), 2d) plac przed Wydziałem Chemii, 2e) plac przed Wydziałem Zarządzania i Komunikacji Społecznej (WZiKS);

3) tereny zielone - 3a) teren za Wydziałem Biochemii, Biofizyki i Biotechnologi (WBBiB), 3b) park za Wydziałem Matematyki i Informatyki (WMiI).

\section{Ocena jakości przestrzeni publicznych kampusu}

Aleja Wawelska

Aleja Wawelska, która stanowi pieszą oś kampusu, łączącą poszczególne jego części i budynki, rozdzielona jest ulicami na trzy części, które powstawały jako kolejne etapy tej inwestycji: część północna w 2008 r., część śodkowa w 2011 r., a część południowa w 2017 r. Wzdłuż najnowszego jej odcinka zabudowa znajduje się tylko po jej stronie północnej, a po południowej od przyległej ulicy oddzielają ją ekrany akustyczne. W pozostałych częściach budynki uniwersyteckie ciągną się po obu stronach alei. 
Odcinki te wyróżniają się w obserwacjach crowdsensingowych. Gęstość obserwacji jest większa w miejscach skrzyżowań z innymi drogami, po których poruszają się użytkownicy kampusu - z ulicami, innymi ciągami pieszymi, przy wyjściach z budynków oraz w miejscach łączenia się z innymi przestrzeniami publicznym (placami i parkami). Pozostałe proste fragmenty nie skłaniały uczestników badania do tak częstego zatrzymywania się i odnotowywania swoich wrażeń. Pokazuje to, że punkty węzłowe stanowią miejsca, na które należy zwrócić szczególną uwagę przy ich planowaniu ze względu na ich znaczenie w odbiorze publicznym (ryc. 2).

Obserwacje uczestników badania pokazują, że najsłabiej użytkowana jest najnowsza część alei, zwłaszcza jej najbardziej południowy kraniec, który stanow przestrzeń służącą jedynie przemieszczaniu się pojedynczych osób między budynkami a wyjściem $z$ terenu uczelni umiejscowionym w ekranach akustycznych. W tej części ciągu pieszego brak miejsc zachęcających do zatrzymania się, z wyjątkiem tarasu oraz terenu, gdzie dochodzi ciąg pieszy łączący dziedzińce południowej części kampusu (2a i 2b) z aleją. Atrakcyjniejsze dla użytkowników zdają się pozostałe dwa fragmenty, zwłaszcza na odcinkach przylegających do parku za WMiI (3b) oraz przy placu przed WFAiIS (2c), stanowiąc ich naturalne przedłużenie, a także przy ul. Gronostajowej w sąsiedztwie działającej wówczas stacji rowerów miejskich.

Ocena założenia urbanistycznego alei wypada niejednoznacznie. Chociaż wyrazistość osi kampusu zapewnia jej, postulowaną przez Kevina Lyncha (1960), czytelność, a skadrowany widok na zamek na Wawelu obrazowość (imageability), to niekorzystnie wpływają na nią niefortunne lub niezrealizowane zakończenia, bez domykających ją dominant urbanistycznych, które mogłyby stanowić cel przemieszczeń i punkt orientacyjny (Lynch 1960; Cullen 1971). Po stronie północnej aleja kończy się gwałtownie skarpą i terenem zielonym, stanowiącymi zaledwie substytut celu podróży. $\mathrm{Z}$ kolei po stronie południowej nie zrealizowano placu miejskiego, więc jeśli ktoś tam dotrze (a wyniki badania pokazują, że nie przebywa tam wiele osób), ma poczucie zagubienia. Na jakość alei jako przestrzeni publicznej rzutuje niekonsekwentna orientacja wejść do budynków wydziałów, generalnie ją ignorujących, oraz monotonne rozwiązania ich fasad i rzutów w skrzydłach przylegających do alei, be aktywnych parterów. Sytuacji nie poprawia monotonny ciąg kilkudziesięciu identycznych ławek, usytuowanych blisko siebie wzdłuż alei, nierzadko zwróconych w stronę ślepych ścian gmachów lub ekranów akustycznych, które nie cieszą się popularnością wśród użytkowników, gdyż nie zapewniają komfortu społecznego (Whyte 2018). Atrakcyjny widok zapewniony jest w okolicy Wydziału Chemii (zachowany fragment starodrzewu) oraz WFAiIS (plac z fontanną), co potwierdzają wyniki badania crowdsensingowego.

W szerszym ujęciu niesatysfakcjonujące pod względem przestrzennym i funkcjonalnym są powiązania głównej osi założenia z otaczającą siecią przestrzeni publicznych, w szczególności z położonymi po południowej stronie terenami mieszkanio- wymi. W rezultacie oba obszary w niewielkim tylko stopniu oddziałują na siebie nie zapewniając efektu synergii w funkcjonowaniu uczelni i miasta.

\section{Place i dziedzińce}

Spośród pięciu wyróżnionych przestrzeni publicznych o charakterze placów i dziedzińców szczególnie pozytywnie wyróżnia się plac przed WFAiIS (2c). Na całym jego terenie odnotowano dużą liczbę użytkowników, wśród których wyraźnie odznaczają się osoby tam się zatrzymujące, realizujące czynności o charakterze opcjonalnym. Niemal wszyscy uczestnicy badania, którzy dotarli do tej przestrzeni, wskazywali na położoną w centralnej części placu fontannę, która była ich zdaniem głównym elementem dodającym atrakcyjności tej przestrzeni (tab. 1, fot. 1). Potwierdza to znaczenie obecności wody dla pozytywnej waloryzacji przestrzeni publicznych (por. Siu Yu Lau i in. 2014). Przynosi ona ochłode w upalne dni na tym placu, który wyróżnia się największym zacienieniem w porównaniu z pozostałymi przestrzeniam tego typu na kampusie UJ. Ułożone wokół niej w półokrąg ławki dodatkowo skupiają aktywność użytkowników tej części kampusu.

Tab. 1. Elementy atrakcyjne analizowanych placów i dziedzińców w opinii uczestników badania crowdsensingowego

Table 1. Attractive elements of campus squares and courtyards according to the crowdsensing survey participants

\begin{tabular}{|c|c|c|c|c|c|c|c|c|c|}
\hline \multirow[b]{2}{*}{\begin{tabular}{|c} 
Przestrzeń \\
publiczna \\
- plac \\
Public \\
space- \\
square
\end{tabular}} & \multirow[b]{2}{*}{$\mathrm{N}$} & \multicolumn{8}{|c|}{$\begin{array}{l}\text { Odsetek respondentów w \% } \\
\text { Share of respondents in \% }\end{array}$} \\
\hline & & $\begin{array}{c}\text { Mała architektura } \\
\text { (tawki, fontannn, } \\
\text { kosze na śmieci } \\
\text { itp.). } \\
\text { Street furniture } \\
\text { (benchese, } \\
\text { fountains, } \\
\text { litter bins, etc.) }\end{array}$ & $\begin{array}{c}\text { Zieleń, } \\
\text { rośliny } \\
\text { Greenery, } \\
\text { plants }\end{array}$ & $\begin{array}{c}\text { Sztuka, } \\
\text { miejsca } \\
\text { symboliczne } \\
\text { Art, symbolic } \\
\text { places }\end{array}$ & $\begin{array}{l}\text { Estetyka, } \\
\text { widok, } \\
\text { krajobraz } \\
\text { Aesthetics, } \\
\text { views, } \\
\text { landscapes }\end{array}$ & $\mid \begin{array}{c}\text { Architektura, } \\
\text { budynek } \\
\text { Architecture, } \\
\text { building }\end{array}$ & \begin{tabular}{c|} 
Pozostała \\
infrastruktura \\
Other \\
infrastructure
\end{tabular} & $\begin{array}{l}\text { Infrastruktura } \\
\text { rowerowa } \\
\text { Bicycle } \\
\text { infrastructure }\end{array}$ & $\begin{array}{c}\text { Cień } \\
\text { Shade }\end{array}$ \\
\hline $2 \mathrm{a}$ & \begin{tabular}{|l|} 
\\
\end{tabular} & 21 & 36 & 45 & 18 & . & & 5 & 2 \\
\hline $2 b$ & \begin{tabular}{|l|}
83 \\
\end{tabular} & 20 & 18 & 6 & 4 & 10 & 18 & 6 & 4 \\
\hline $2 c$ & \begin{tabular}{|l|}
42 \\
\end{tabular} & 90 & 29 & . & 14 & 14 & 2 & 2 & 10 \\
\hline $2 \mathrm{~d}$ & 33 & 6 & 24 & . & 18 & 42 & 3 & 15 & 12 \\
\hline $2 e$ & 27 & 4 & 26 & 30 & 33 & 15 & 37 & 22 & . \\
\hline $\begin{array}{c}\text { Razem } \\
\text { Total }\end{array}$ & 241 & 29 & 26 & 16 & 14 & 13 & 11 & 8 & 5 \\
\hline
\end{tabular}

Objaśnienia: oznaczenia przestrzeni publicznych - zobacz ryc. 1

Explanations: numbers of public spaces - see fig. 1. 


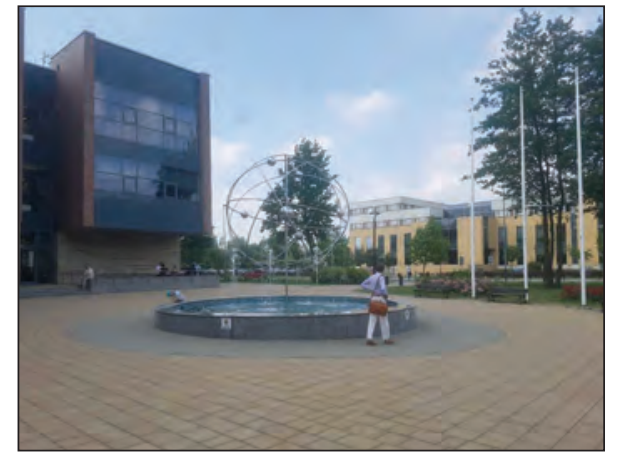

OBS421: Fontanna (Fountain)

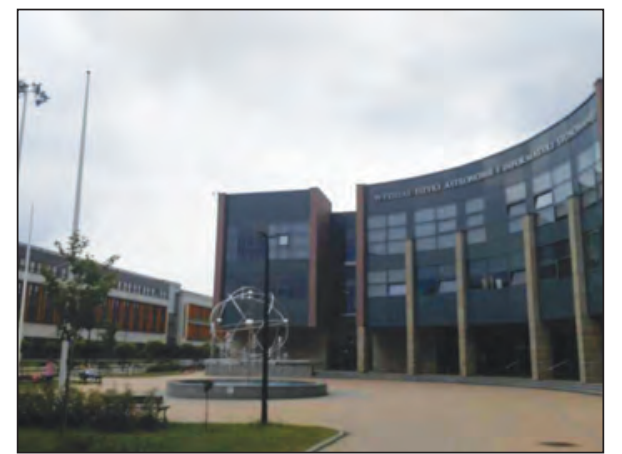

OBS677: Fontanna, dużo cieni, wysokie drzewa, budynek (Fountain, a lot of shade, tall trees, building)

Fot. 1. Przykłady atrakcyjnych elementów placu przed WFAiIS (2c) w opinii uczestników badania

Photo 1. Examples of attractive elements of the WFAiIS square (2c) according to the crowdsensing survey participants

Źródto: zdjęcia i komentarze uczestników badania crowdsensingowego.

Source: photos and comments of the crowdsensing survey participants.

Tab. 2. Elementy nieatrakcyjne analizowanych placów i dziedzińcow w opinii uczestników badania crowdsensingowego

Table 2. Unattractive elements of campus squares and courtyards according to the crowdsensing survey participants

\begin{tabular}{|c|c|c|c|c|c|c|c|c|}
\hline \multirow[b]{2}{*}{$\begin{array}{c}\text { Przestrzeń } \\
\text { publiczna } \\
\text { - plac } \\
\text { Public } \\
\text { space- } \\
\text { square }\end{array}$} & \multirow[b]{2}{*}{$N$} & \multicolumn{7}{|c|}{$\begin{array}{l}\text { Odsetek respondentów w \% } \\
\text { Share of respondents in \% }\end{array}$} \\
\hline & & \begin{tabular}{|c|} 
Braki \\
w matej \\
architekturze \\
Deficiencies \\
in street \\
furniture
\end{tabular} & $\begin{array}{c}\text { Brak } \\
\text { cienia } \\
\text { No shade }\end{array}$ & $\begin{array}{c}\text { Infrastruktura } \\
\text { samochodowa } \\
\text { Car infrastructure }\end{array}$ & $\begin{array}{c}\text { Estetyka, } \\
\text { widok, } \\
\text { krajobraz } \\
\text { Aesthetics, } \\
\text { views, } \\
\text { landscapes }\end{array}$ & $\begin{array}{l}\text { Brak zieleni } \\
\text { No greenery }\end{array}$ & $\begin{array}{l}\text { Architektura, } \\
\text { budynek } \\
\text { Architecture, } \\
\text { building }\end{array}$ & $\begin{array}{c}\text { Niezagospodaro- } \\
\text { wany, zaniedbany } \\
\text { teren } \\
\text { Undeveloped, } \\
\text { neglected area }\end{array}$ \\
\hline $2 a$ & \begin{tabular}{|l|l}
56 \\
\end{tabular} & 13 & 38 & 7 & 9 & 2 & 5 & \\
\hline $2 b$ & \begin{tabular}{|l|}
83 \\
\end{tabular} & 18 & 7 & 14 & 10 & 8 & 10 & 10 \\
\hline $2 c$ & 42 & 17 & 7 & 5 & 5 & 2 & . & . \\
\hline $2 d$ & 33 & 24 & & 21 & 9 & 15 & 3 & 6 \\
\hline $2 e$ & \begin{tabular}{|l|l}
27 \\
\end{tabular} & 19 & 15 & 11 & 7 & 11 & . & 4 \\
\hline $\begin{array}{c}\text { Razem } \\
\text { Total }\end{array}$ & 241 & 17 & 14 & 12 & 8 & 7 & 5 & 5 \\
\hline
\end{tabular}

Objaśnienia: oznaczenia przestrzeni publicznych - zobacz ryc. 1.

Explanations: numbers of public spaces - see fig. 1 .
Plac ten utworzono przez wycofanie bryły w narożniku alei Wawelskiej i ul. Łojasiewicza, dzięk czemu powstała niewielka „kieszeń", która korzysta z dobrych powiązań wizualnych i pieszych, ale jednocześnie cechuje się pewną odrębnością i w odróżnieniu od powtarzalnej aranżacji alei, sprzyja przystawaniu w tym miejscu na dłużej. Wklęsła fasada wejściowa budynku nadaje placowi czytelne granice i właściwą skalę.

Jego przeciwieństwem w świetle wyników badań jest plac przed Wydziałem Chemii (2d). Główne wejście do jego siedziby prowadzi jednak nie z alei Wawelskiej, a od prostopadłej ul. Łojasiewicza. Znajduje się przed nim rozległa brukowana nawierzchnia pozbawiona drzew i małej architektury, przez co przestrzeń ta ma charakter komunikacyjny i reprezentacyjny,

ale nie sprzyja przebywaniu tam (tab. 2, fot. 2). Przez plac przemieszczały się bez zatrzymywania pojedyncze osoby. Północną ścianę placu wejściowego stanow rosnący wzdłuż cieku wodnego pas krzewów i wysokich drzew - nielicznej, a przez to zyskującej na atrakcyjności zieleni wysokiej na terenie kampusu. Nie jest on jednak powiązany funkcjonalnie z placem, przez co nie zatrzymuje na dłużej użytkowników. W tym kontekście warto dodać, że wspólnym problemem większości analizowanych przestrzeni publicznych jest bardzo mała liczba dużych drzew sprzed okresu budowy kampusu. Nie zrealizowano również zalecanych w planie koordynacyjnym nasadzeń wyprzedzających.

Pośrednim poziomem atrakcyjności, zgodnie z przyjętym wskaźnikiem liczebności użytkowników i ich zachowania, odznacza się plac wejściowy do WZiKS (2e) Uczestnicy badania doceniali niektóre walory estetyczne placu, a w szczególności obecność dużych kolorowych liter „JU4U”, czyli Jagiellonian University For You, które przy pozostałych mankamentach placu stanowią wyrazisty symboliczny punkt, przy którym wielu studentów robi zdjęcia po obronie prac dyplomowych (fot. 3). Plac ten umiejscowiony jest naprzeciw wejścia do Wydziału Chemii, jednak 


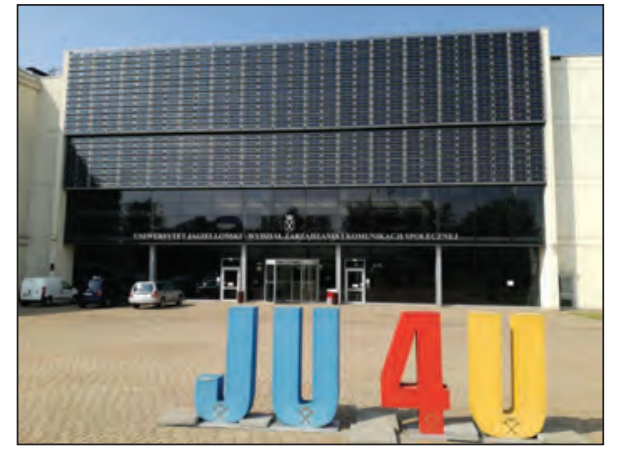

OBS307: Wykorzystanie energii słoneczne (The use of solar energy)

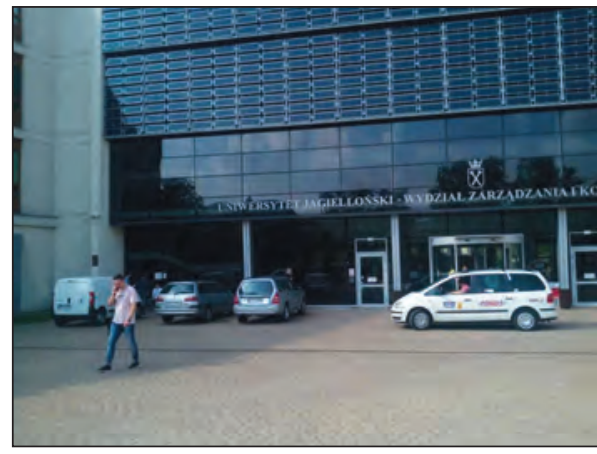

OBS192: Parking tuż przed wejściem (Parking lot right in front of the entrance)

Fot. 3. Przykłady atrakcyjnych (z lewej) i nieatrakcyjnych (z prawej) elementów placu przed WZiKS (2e) w opinii uczestników badania

Photo 3. Example of attractive (left) and unattractive (right) elements of the WZiKS square (2e) according to the crowdsensing survey participants

Źródto: zdjęcia i komentarze uczestników badania crowdsensingowego.

Source: photos and comments of the crowdsensing survey participants.

ze względu na dzieląca je ulice i ciek wodny nie jest z nim powiązany ani funkcjonalnie, ani wizualnie. Plac przed WZiKS również nie jest odpowiednio powiązany z aleją Wawelską. Do jego mankamentów - na co wskazywali respondenci - należy zaliczyć brak drzew i co za tym idzie - cienia, istotnego w kontekście południowo-zachodniej ekspozycji. Plac ten pełni przede wszystkim funkcję reprezentacyjną, co nie przeszkadza temu, by parkowały tam samochody osobowe i dostawcze. Ich obecność oraz niedobór miejsc siedzących i brak zacienienia zniechęcają zdaniem badanych do spędzania tam czasu. Jednocześnie z powodu nieskoordynowanego z kompozycją przestrzenną kampusu położenia przystanków tramwajowych użytkownicy chętniej korzystają z bliższego przystankom tramwajowym wejścia bocznego.

Odmienny charakter mają dwie kolejne przestrzenie publiczne, stanowiące części rozległego dziedzińca w południowej, najstarszej części kampusu, rozdzielone wbudowanym w skarpę pawilonem techniczno-gospodarczym. Funkcję przestrzeni publicznej w większym stopniu spełnia przestrzeń między skrzydłami KNB (2a) z charakterystycznym zegarem słonecznym, który dla uczestników badania stanowi najbardziej rzucający się w oczy element. Opadający w kierunku północnym dziedziniec zagospodarowany został jako teren zielony z brukowanymi nawierzchniam dojść i dojazdów. W jego centralnej części oprócz zegara mieści się krąg pomników, ławek i drzew. Ściany wnętrza urbanistycznego dziedzińca są monotonne, urozma-

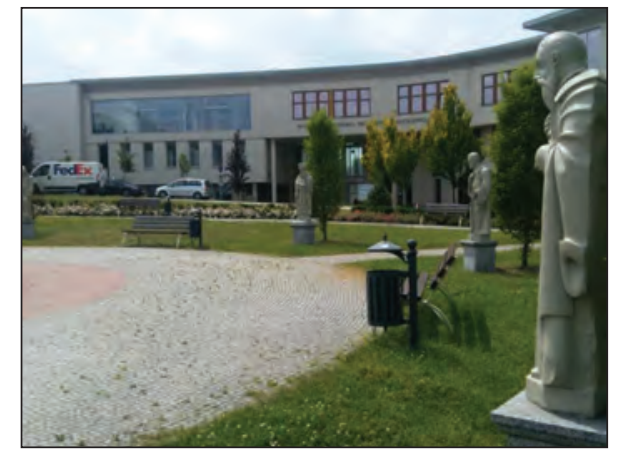

OBS707: Posągi (Statues)

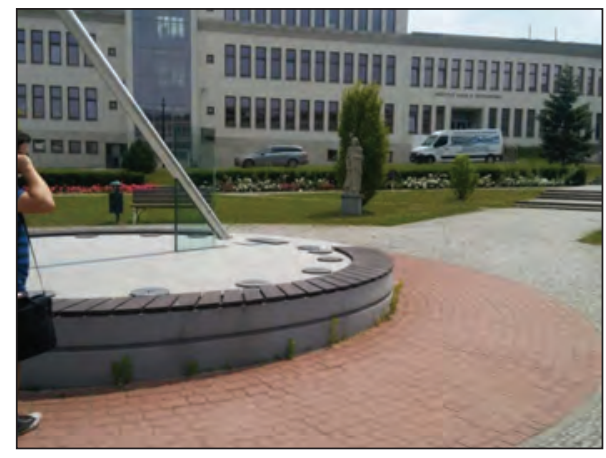

OBS707: Brak cienia (No shade)
Fot. 4. Przykłady atrakcyjnych (z lewej) i nieatrakcyjnych (z prawej) elementów dziedzińca w Kompleksie Nauk Biologicznych (2a) w opinii uczestników badania

Photo 4. Example of attractive (left) and unattractive (right) elements of the Biological Science Complex courtyard (2a) according to the crowdsensing survey participants

Źródto: zdjęcia i komentarze uczestników badania crowdsensingowego.

Source: photos and comments of the crowdsensing survey participants.

icone jedynie pionami wysuniętych klatek schodowych, a w strefie parteru martwe, z nielicznymi oknami i drzwiami. Aranżacja dziedzińca cechuje się osiowością i reprezentacyjnością. Całość wyróżnia się pozytywnie klarownością kompozycji urbanistycznej, zróżnicowaniem nawierzchni, w tym dużym udziałem terenu zielonego i wykorzystaniem spadku terenu.

Respondenci doceniali obecność zieleni i ławek, ale podkreślali brak cienia, którego nie dawały nasadzone tam niewielkie drzewa szczepione na pniu ${ }^{4}$. Dodatkowo pojedynczy badani zwracali uwagę na brak prywatności - przy braku większych drzew osoby tam przebywające mogły mieć poczucie bycia obserwowanym prze osoby w budynkach, niczym w panoptykonie. Wszystko to sprawia, że przebywało tam przeciętnie mniej osób niż na innych, bardziej atrakcyjnych placach kampusu (fot. 4). Przestrzeń ta wykorzystywana jest zarówno jako miejsce spędzania wolnego czasu, jak i ciąg komunikacyjny między poszczególnymi skrzydłami kompleksu. Wpływa na to brak dodatkowych funkcji, które uaktywniłyby osoby korzystające $\mathrm{z}$ tej przestrzeni. Istotnym mankamentem jest również słabe powiązanie przestrzeni dziedzińca KNB z aleją. 
Odmienny charakter ma wnętrze urbanistyczne ukształtowane między gmacham MCB, CEP i ING (2b). Jest ono słabo powiązane z położonym obok dziedzińcem KNB. Choć prowadzą z niego wejścia do pięciu budynków, co gwarantuje niemałą liczbę użytkowników, to relacje przestrzenne między budynkami są przypadkowe, a brak czytelności pogłębiony jest przez niezgrabne rozplanowanie ciągów pieszych i kołowych. Niespójność zabudowy i prowadzących do niej chodników oraz brak czytelnego powiązania tego rozległego dziedzińca z aleją Wawelską sprawiają, że jego przestrzeń jest chaotyczna. Uczestnicy badania zwracali uwagę na dominujące w tej przestrzeni parkingi samochodowe, przez które zmuszonych jest przechodzić wielu pieszych (fot. 5). Estetykę dodatkowo zaburzają, ich zdaniem, wspomniane budynki gospodarcze. Jedynym interesującym akcentem dla części badanych był zlokalizowany tam ogródek meteorologiczny, który nie skłania jednak do żadnych aktywności. Doceniano również obecność ławek i zieleni urządzonej w niektórych jego częściach. Mimo to wyniki obserwacji wskazują, że niemal w całości stanowi on strefę koniecznego przemieszczania się użytkowników kampusu, którzy nie znajdują w tej przestrzeni (nawet w jej częściach zagospodarowanych, np. przed CEP) pretekstu do zatrzymania się i spotkania z innymi osobami. Jeden z respondentów zauważył jednak „duży potencjał na dobre zagospodarowanie rekreacyjne” tej przestrzeni. Centrum Edukacji Przyrodniczej stanowić może instytucję, która

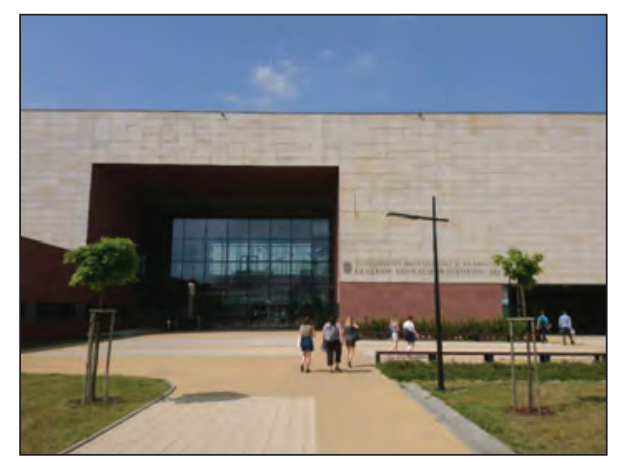

OBS516: Centrum Edukacji Przyrodnicze (Nature Education Centre)

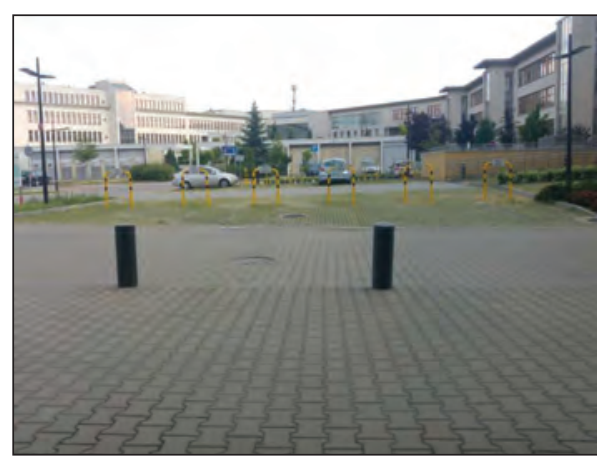

OBS074: Brak roślinności naprzeciw siedzeń (No greenery in front of benches)
Fot. 5. Przykłady nieatrakcyjnych elementów dziedzińca między MCB, CEP i ING (2b) w opinii uczestników badania

Photo 5. Example of unattractive elements of the courtyard between the MCB, the CEP and the ING (2b) according to the crowdsensing survey participants

Źródto: zdjęcia i komentarze uczestników badania crowdsensingowego.

Source: photos and comments of the crowdsensing survey participants. mogłaby zaktywizować tę przestrzeń dzięki organizowanym przez nie, również w przestrzeni publicznej, wydarzeniom.

\section{Tereny zielone}

Kontrastowe pod względem atrakcyjności są w stosunku do siebie dwa tereny zielone wchodzące w skład kampusu (tab. 3 i 4). Zdecydowanie korzystniej wypada położony w północnej części założenia park za WMiI (3b). Usytuowany jest on w pobliżu zachodniego końca alei Wawelskiej i wobec braku innych rozwiązań stanowi jej kulminację. Studenci biorący udział w badaniu chętnie zapuszczali się w jego głąb, odnotowując obecność licznych grup osób przebywających dłużej na tym obszarze - nie tylko w samym parku, ale również w jego strefie brzeżnej przy alei. Respondenci bardzo doceniali jedyne tak duże w skali kampusu zagęszczenie starych drzew sprzed budowy kampusu, możliwość korzystania z walorów widokowych, kameralność zapewniającą ciszę i spokój, a także możliwość aktywnego wypoczynku na siłowni zewnętrznej (fot. 6). Jako mankament wskazywali wyraźny niedobór miejsc do siedzenia (różnego rodzaju siedzisk lub altan), brak koszy na śmieci oraz utwardzonych ścieżek.

Drugi z terenów zielonych za WBBiB (3a) ma odmienny charakter, co znalazło odzwierciedlenie w wynikach obserwacji i ocenach uczestników badania. $Z$ punktu

Tab. 3. Elementy atrakcyjne w analizowanych terenach zielonych w opinii uczestników badania crowdsensingowego

Table 3. Attractive elements of campus green areas according to the crowdsensing survey participants

\begin{tabular}{|c|c|c|c|c|c|c|c|}
\hline \multirow{2}{*}{$\begin{array}{c}\text { Przestrzeń } \\
\text { publiczna } \\
\text { - teren } \\
\text { zielony } \\
\text { Public } \\
\text { space - } \\
\text { green area }\end{array}$} & \multirow[b]{2}{*}{$\mathrm{N}$} & \multicolumn{6}{|c|}{$\begin{array}{l}\text { Odsetek respondentów w \% } \\
\text { Share of respondents in \% }\end{array}$} \\
\hline & & $\begin{array}{l}\text { Zieleń, rośliny } \\
\text { Greenery, plants }\end{array}$ & $\begin{array}{c}\text { Sitownia } \\
\text { zewnętrzna } \\
\text { Outdoor gym }\end{array}$ & $\begin{array}{l}\text { Estetyka, widok, } \\
\text { krajobraz } \\
\text { Aesthetics, views, } \\
\text { landscapes }\end{array}$ & $\begin{array}{l}\text { Cisza, spokój } \\
\text { Silence, peace }\end{array}$ & $\begin{array}{c}\text { Wolna, otwarta } \\
\text { przestrzeń } \\
\text { Open space }\end{array}$ & \begin{tabular}{|c|} 
Mała architektura \\
(tawki, koszes \\
na śmieci itp.) \\
Street furniture \\
(benches, litter \\
bins, etc.)
\end{tabular} \\
\hline $3 a$ & 53 & 28 & 51 & 32 & 13 & 21 & . \\
\hline $3 b$ & 62 & 66 & 39 & 21 & 15 & 3 & 15 \\
\hline $\begin{array}{c}\text { Razem } \\
\text { Total }\end{array}$ & 115 & 49 & 44 & 26 & 14 & 11 & 8 \\
\hline
\end{tabular}

Objaśnienia: oznaczenia przestrzeni publicznych - zobacz ryc. 1.

Explanations: numbers of public spaces - see fig. 1. 
Tab. 4. Elementy nieatrakcyjne w analizowanych terenach zielonych w opinii uczestników badania crowdsensingowego

Table 4. Unattractive elements of campus green areas according to the crowdsensing survey participants

\begin{tabular}{|c|c|c|c|c|}
\hline \multirow{2}{*}{$\begin{array}{l}\text { Przestrzeń publiczna } \\
\text { - teren zielony } \\
\text { Public space - green } \\
\text { area }\end{array}$} & \multirow[b]{2}{*}{$\mathrm{N}$} & \multicolumn{3}{|c|}{$\begin{array}{l}\text { Odsetek respondentów w \% } \\
\text { Share of respondents in \% }\end{array}$} \\
\hline & & $\begin{array}{c}\text { Braki w matej } \\
\text { architekturze } \\
\text { Deficiencies in street } \\
\text { furniture }\end{array}$ & $\begin{array}{l}\text { Braki w infrastrukturze } \\
\text { pieszej } \\
\text { Deficiencieses in pedestrian } \\
\text { infrastructure }\end{array}$ & $\begin{array}{l}\text { Brak cienia } \\
\text { No shade }\end{array}$ \\
\hline $3 a$ & 53 & 26 & 2 & 13 \\
\hline $3 b$ & 62 & 35 & 21 & 2 \\
\hline $\begin{array}{c}\text { Razem } \\
\text { Total }\end{array}$ & 115 & 31 & 12 & 7 \\
\hline
\end{tabular}

Objaśnienia: oznaczenia przestrzeni publicznych - zobacz ryc. 1.

Explanations: numbers of public spaces - see fig. 1 .

widzenia kompozycji przestrzennej kampusu ma on marginalne znaczenie. Choc to obszar przeznaczony w miejscowym planie zagospodarowania przestrzennego pod zieleń urządzoną i zbiornik retencyjny, to jest on wizualnie odcięty zarówno od głównej osi kampusu (1), jak i od dziedzińca KNB (2a), stanowiących główne przestrzenie publiczne tego obszaru. Jedyne istniejące, wąskie połączenie tego terenu zielonego z resztą kampusu między WBBiB a MCB jest rozwiązaniem przestrzennie nieczytelnym i nieadekwatnym. Znaczenie tego terenu zielonego może wzrosnąć, jeśli zrealizowany zostanie planowany plac na końcu alei, dzięki czemu będzie mógł zostać włączony w sieć przestrzeni publicznych kampusu. Obserwacje tego obszaru pokazują, że jest on jednak chętnie wykorzystywany przez mieszkańców sąsiednich osiedli.

Studenci biorący udział w badaniu nie czuli się jednak zachęceni do eksploracji tego terenu, pozostając na jego obrzeżach. Brak drzew i otwarta przestrzeń dawała im możliwość podziwiania krajobrazu rozciągającego się na zachód od kampusu. W porównaniu z parkiem za WMiI (3b) respondenci w mniejszym stopniu doceniali zagospodarowanie zieleni na tym obszarze. Atutem tej przestrzeni jest, ich zdaniem, siłownia zewnętrzna (fot. 7). Niższą atrakcyjność potwierdzają obserwacje zachowań użytkowników tego terenu: byli oni mniej liczni, niektórzy spędzali tam czas, ale inn jedynie przez niego przechodzili. Wyniki potwierdzają utrudnione i mało czytelne strefy dojścia do tego terenu z kampusu, w których w trakcie badania zwykle nie odnotowano obecności innych osób (fot. 8).

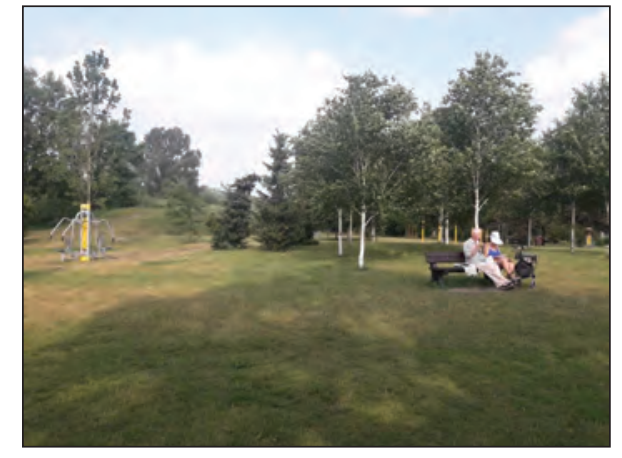

OBS101: Bardzo zielono (Very green)

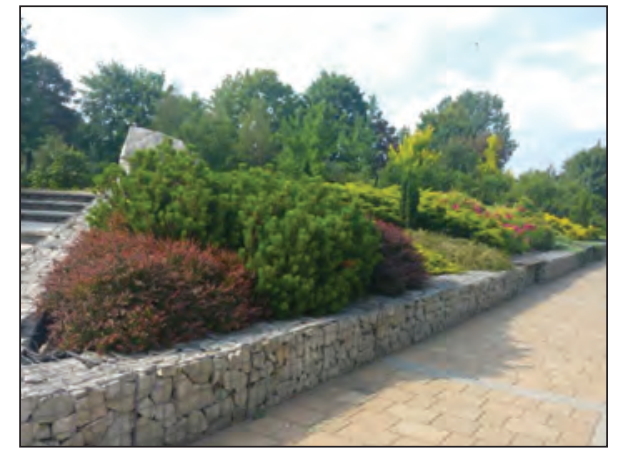

OBS174: Układ florystyczny (Floral arrangements)
Fot. 6. Przykłady atrakcyjnych elementów parku za WMiI (3b) w opinii uczestników badania Photo 6. Example of attractive elements of the park behind the WMIiI (3b) according to the crowdsensing survey participants

Źródto: zdjęcia i komentarze uczestników badania crowdsensingowego

Source: photos and comments of the crowdsensing survey participants.

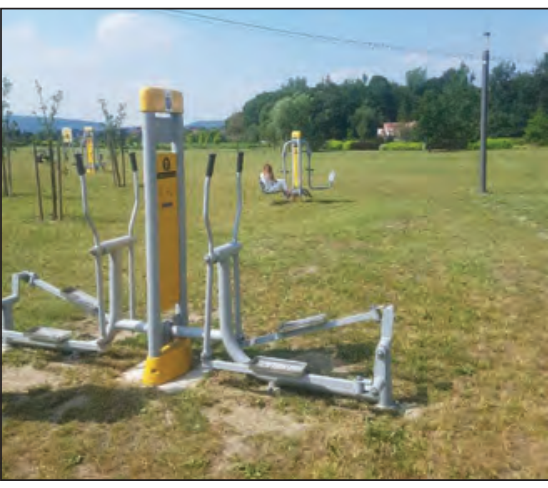

OBS576: Siłownia (Outdoor gym)

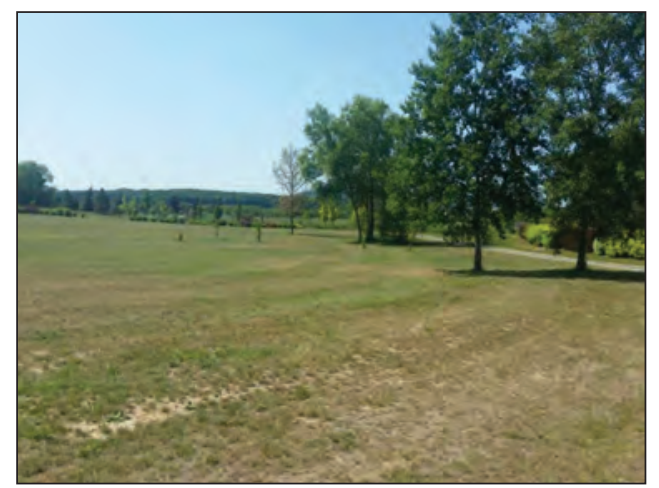

OBS638: Zieleń, otwarta przestrzeń, spokój (Greenery, open space, peace)
Fot. 7. Przykłady atrakcyjnych elementów parku za WBBiB (3a) w opinii uczestników badania Photo 7. Example of attractive and unattractive elements of the park behind the WBBiB (3a) according to the crowdsensing survey participants

Źródto: zdjęcia i komentarze uczestników badania crowdsensingowego.

Source: photos and comments of the crowdsensing survey participants. 


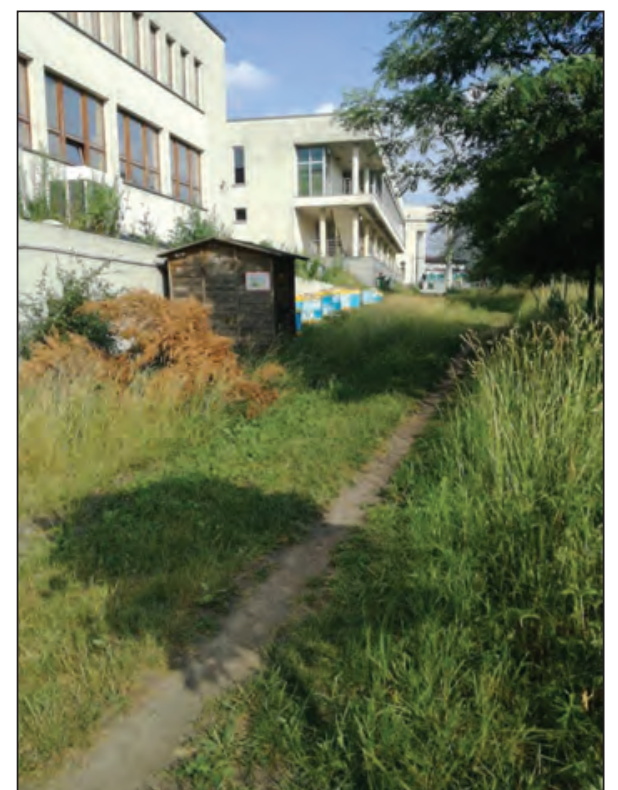

OBS094: Pszczoły przy ścieżce, która prowadz na teren silowni (Bees by the path that leads to the outdoor gym)

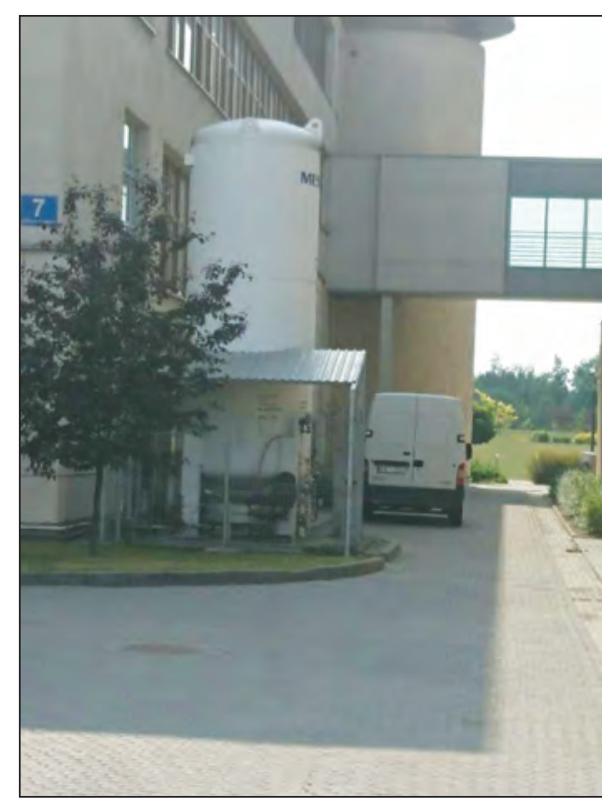

OBS328: Ten bojler (This tank
Fot. 8. Przykłady nieatrakcyjnych ścieżek do parku za WBBiB (3a) w opinii uczestników badania

Photo 8. Example of unattractive paths to the park behind the WBBiB (3a) according to the crowdsensing survey participants

Źródto: zdjęcia i komentarze uczestników badania crowdsensingowego

Source: photos and comments of crowdsensing survey participants.

\section{Dyskusja i wnioski}

Kampus 600-lecia Odnowienia Uniwersytetu Jagiellońskiego wraz z przyległym parkiem technologicznym stanowi jedną z najbardziej wyrazistych kreacji przestrzennych Krakowa, powstałych po 1989 r. Jej istotą jest osiowa konfiguracja wnętrz urbanistycznych, która stanowi rozwinięcie charakterystycznego elementu kompozycji urbanistycznej miasta, jakim są osie kompozycyjne wraz z zamknięciami (Motak 2012). Sile tej kompozycji ustępują jednak zrealizowane rozwiązania przestrzenne, funkcjonalne i komunikacyjne kampusu, a także niskiej jakości detal urbanistyczny. Wynikają one z braku koordynacji pomiędzy narzuconym przebiegiem alei a rzeczywistymi kierunkami przemieszczania się użytkowników kampusu do i z przystanków komunikacji publicznej. Związane to jest również z późniejszymi decyzjami projektowymi odnośnie do orientacji wejść do poszczególnych obiektów, kreowania przedpól i aneksów alei.

$\mathrm{Na}$ podstawie obserwacji dokonanych przez uczestników badania crowdsensingowego oraz oceny eksperckiej autorów i autorek tekstu stwierdzić można, że większość analizowanych placów, dziedzińców, ciągów pieszych i terenów zielonych nie spełnia funkcji, jakich oczekuje się od współczesnych przestrzeni publicznych por. Carmona 2015). Nie skłaniają one do zatrzymania się, do spędzenia w nich czasu, nie sprzyjają zaplanowanym ani przypadkowym spotkaniom. Większość z nich nie spełnia bowiem podstawowych potrzeb użytkowników tego rodzaju przestrzeni (por. Göçer i in. 2018): wygody, możliwości odpoczynku, zaangażowania się w działania, odkrywania i rozrywki. Stosunkowo najkorzystniej pod tym względem wypadają dwie, pozytywnie wyróżniające się w skali kampusu, przestrzenie - plac przed WFAiIS (2c) oraz niewielki park za WMiI (3a). Na ich atrakcyjność składa się kilka czynników: czytelnie określone ściany, obecność wody i cienia oraz układ ławek w pierwszym przypadku, zachowane stare drzewa, możliwość odpoczynku biernego lub aktywnego (na siłowni zewnętrznej) w drugim przypadku. Jako kontrprzykłady wskazać można plac przed Wydziałem Chemii (2d) oraz dziedziniec między MCB, CEP i ING (2b).

Zastosowana technika masowego zbierania danych na temat zachowań użytkowników w badanej przestrzeni przyniosła interesujące wyniki, które potwierdziły wiele obserwacji i ocen autorów oraz autorek tekstu. $Z$ techniką tą wiążą się jednak zastrzeżenia typowe dla metod badań społecznych, takie jak brak pogłębionej wiedzy na temat powodów takiej, a nie innej oceny danej przestrzeni lub przyczyn obserwowanych zachowań użytkowników oraz trudności w interpretacji materiału wizualnego. Wymagają tym samym uzupełnienia dodatkowymi metodami badań jakościowych, np. spacerami badawczymi. Warto również dodać, że mimo, zdawałoby się, atrakcyjnej formy badań i łatwości korzystania z aplikacji mobilnej napotkaliśmy trudności w rekrutacji uczestników, którymi ostatecznie zostali studenci biorący udział w ćwiczeniach terenowych. W konsekwencji w badaniu nie uczestniczyli reprezentanci wielu grup, które korzystają z tego obszaru. Może to również świadczyć o ciągle niewielkim zainteresowaniu użytkowników kampusu przestrzeniami, w których przychodzi im studiować i pracować. W przyszłości wskazane byłoby poszerzenie badania o inne kategorie osób korzystających z terenu kampusu z użyciem szerszego zestawu metod badawczych.

Wracając do oceny przestrzeni publicznych III Kampusu UJ, zauważyć należy wyraźny prymat reprezentacyjności i monumentalności nad komfortem i różnorodnością. Za wytyczeniem alei w planie koordynacyjnym nie nastąpiło rozwinięcie jej idei w bardziej szczegółowej skali, które uwzględniałoby powiązania z otoczeniem, rozwiązania stref wejść do budynków itd. Powstała przestrzeń jest monotonna; 
nie zapewnia społecznego komfortu, którego przejawem jest możliwość wyboru swojego miejsca w mieście: w słońcu lub w cieniu, na widoku lub w ukryciu, samemu lub w grupie, przodem lub tyłem, widzenia lub bycia widzianym itd. (por. Gehl 2009; Whyte 2018). Aleja sprawia wrażenie przestrzeni całkowicie podporządkowanej geometrii, niedającej miejsca na mniej formalne aktywności Stanowi ona wytwór źle pojętego prestiżu i nowoczesności, by nie powiedzieć „zapóźnionej nowoczesności”. Daleko jej bowiem do wizji krajobrazu naukowego dającego możliwość nawiązywania kontaktów, wymiany doświadczeń, eksperymentowania. Cały kompleks nie pełni funkcji pełnowartościowego miasteczka, a jedynie zgrupowania wyspecjalizowanych obiektów nauki i edukacji, odizolowanych i niepowiązanych ze sobą. Przestrzeń między budynkami służy niemal wyłącznie koniecznemu przemieszczaniu się, nie tworzy warunków do spędzania w niej czasu. Słabości i mankamenty przestrzeni publicznej kampusu nie sprzyjają interakcjom pomiędzy badaczami i studentami poszczególnych wydziałów, ich sieciowaniu, a w konsekwencji - interdyscyplinarności.

Nie sposób nie wspomnieć o zaledwie przeciętnym poziomie zrealizowanej architektury, uzyskanej w powszechnie krytykowanym trybie przetargowym z dominującym kryterium niskiej ceny. Brak na kampusie architektury wybitnej; podobnie nieemocjonująca i przeciętna jest przestrzeń między budynkami. Dodatkowo jest ona mało przyjazna - brak w niej wyznaczonych miejsc do nauki, do spożywania posiłków na zewnątrz, do organizacji działań społecznych i kulturalnych. Studenci i pracownicy przemieszczają się tym samym głównie między budynkami a przystankami lub parkingami. Niemal zupełnie brakuje w niej usług gastronomicznych, które mogłyby je ożywić - w tym kontekście niewykorzystan jest potencjał tarasu przy południowym krańcu alei Wawelskiej, przy którym działa kawiarnia. Większość usług schowanych jest wewnątrz budynków, co ogranicza ich wykorzystanie przez osoby z zewnątrz - negatywne konsekwencje tej sytuacji uwidoczniły się w szczególności w trakcie pandemii koronawirusa. Wyraźne jest również podporządkowanie układu przestrzennego ruchowi samochodowemu drogi dojazdowe przecinają główny ciąg pieszy kampusu bez wyznaczonych przejść dla pieszych, a parkingi zajmują znacząca czesść terenu, wpływając na negatywny odbiór przestrzeni. Mimo dominacji udziału pieszych użytkowników na terenie kampusu ich potrzeby nie są pierwszoplanowe. W konsekwencji, w naszej opinii, wszystko to składa się na utrudniony proces kształtowania się poczucia przynależności i tożsamości z kampusem wśród członków społeczności akademickiej, co dodatkowo potęgują ograniczone możliwości współdecydowania o przestrzeni, w której przebywają.

Paradoksalnie, mimo znaczących barier przestrzennych między kampusem a jego otoczeniem, obszar uczelni, zwłaszcza aleja Wawelska i tereny zielone, odwiedzane są głównie w celach rekreacyjnych przez mieszkańców okolicznych osiedli, które borykają się z jeszcze większym niedoborem dobrej przestrzeni publicznej i terenów zielonych. Społeczność akademicka i okoliczni mieszkańcy zdają się jednak rozmijać na terenie kampusu i nie mają zbyt dużo okazji, by się spotkać. Zarządzający przestrzenią kampusu w sposób bardziej świadomy i otwarty powinni również zwracać uwagę na użytkowników zewnętrznych, co można traktować nie tylko jako spełnianie społecznej misji uniwersytetu, lecz także inwestycję w przyszłość poprzez budowanie przyjaznego wizerunku uczelni.

Następują jednak powolne zmiany. Czesść postulatów wynikających z tych i innych badań prowadzonych przez inicjatywę Kampus+ oraz innych głosów przedstawicieli społeczności akademickiej została w ostatnich dwóch latach wdrożona. Posadzono większe okazy drzew i ograniczono koszenie trawników, co przyczyniło się do podniesienia atrakcyjności alei Wawelskiej oraz dziedzińca wewnątrz KNB. Zorganizowano akcje wspólnego siania łąk kwietnych i sadzenia bluszczu wzdłuž ekranów. Realizowany jest wyłoniony w konkursie projekt zagospodarowani terenu zielonego przy południowym odcinku alei Wawelskiej. Przy współpracy $\mathrm{z}$ miastem wprowadzono rozwiązania w zakresie uspokojenia ruchu samochodowego i poprawy bezpieczeństwa pieszych.

Wymagany jest jednak dalszy wspólny namysł oraz podejmowanie działań na rzecz ożywienia przestrzeni publicznych kampusu - zarówno pod względem ich wyglądu fizycznego, jak i aktywności społecznych, które mogłyby oferować. Równocześnie w obliczu postępującej katastrofy klimatycznej należy realizować interwencje zorientowane na adaptowanie przestrzeni uczelni do zachodzących zmian. W tym kontekście kampus nie może być przestrzenią traktowaną jako „skończona”, powinien być otwarty na możliwości eksperymentowania i prototypowania przestrzeni (por. Whyte 2018), np. w ramach prowadzonych zajęć lub uczelnianego budżetu partycypacyjnego, dzięki czemu mógłby być laboratorium nowych rozwiązań, powstających przy współpracy uczelni, społeczeństwa i gospodarki, spełniając przy tym istotny walor edukacyjny.

\section{Literatura}

Aanensen D.M., Huntley D.M., Menegazzo M., Powell C.I., Spratt B.G., 2014, EpiCollect+ linking smartphones to web applications for complex data collection projects, F1000 Research, 3 , https://pubmed.ncbi.nlm.nih.gov/25485096/ (dostęp: 15.04.2020).

Abu-Ghazzeh T.M., 1999, Communicating behavioural research to campus design, factors affecting perception and use of outdoor spaces at the University of Jordan, Journal of Environment and Behaviour, 31 (6), 764-804.

Ahmed S., Haklay M., Tacoli C., Githiri G., Dávila J.D., Allen A., Fèvre E,M., 2019, Participatory mapping and food-centred justice in informal settlements in Nairobi, Kenya, Geo: Geography and Environment, e00077, https://doi.org/10.1002/geo2.77 (dostęp: 10.09.2020). 
Alexander C., 2008, Języ warorów: miasta - budynki - konstrukcja, Gdańskie Wydawnictwo Psychologiczne, Gdańsk.

Aydin D., Ter U., 2008, Outdoor space quality: case study of a university campus plaza, Archnet-IJAR: International Journal of Architectural Research, 2 (3), 189-203.

Bathelt H., Malmberg A., Maskell P., 2004, Clusters and knowledge: local buzz, global pipelines and the process of knowledge creation, Progress in Human Geography, 28 (1), 31-56.

Biddulph M., 1999, Bringing vitality to a campus environment, Urban Design International, $4(3-4), 153-166$.

Bierwiaczonek K., Lewicka B., Nawrocki T., 2012, Rynki, malle i cmentarze. Przestrzeń publiczna miast ślaskich w ujęciu socjologicznym, Wydawnictwo Nomos, Kraków.

Bierwiaczonek K., 2018, Miejskie przestrzenie publiczne i ich spoteczne znaczenia - próba systematyzacji, Przegląd Socjologiczny, 1, 25-48.

Böhm A., 2008, Miejscowy plan zagospodarowania przestrzennego III Kampusu UJ, Czasopismo Techniczne, 1-A, 69-76.

Bryant J., Cordell M., Deihl G., Gebrezgi A., Layden T., Marshall T.A., Newman K., PittsLore A., Sobieck L., 2013, Finding nature in your neighborhood: a field mapping protocol for community based assessment of greenspace access, Asset Mapping: Community Geography Project, 8, http://pdxscholar.library.pdx.edu/ims_assestmapping/8 (dostęp: 20.04.2020).

Bryx M., 2013, Rewitalizacja præestrzeni akademickiej, Problemy Rozwoju Miast 10 (1), 7-14.

Brzozowska B., 2014, Miasto kreatywne - miasto studentyfikowane?, [w:] P. Sztompka, K. Matuszek (red.), Idea uniwersytetu. Reaktywacja, Wydawnictwo Uniwersytetu Jagiellońskiego, Kraków, 151-164.

Burke J., Estrin D., Hansen M., Parker A., Ramanathan N., Reddy S., Srivastava M.B., 2006, Participatory sensing, UCLA, Center for Embedded Network Sensing, https://escholarship. org/uc/item/19h777qd (dostęp: 30.03.2020).

Carmona M., 2015, Re-theorising contemporary public space: a new narrative and a new normative, Journal of Urbanism: International Research on Placemaking and Urban Sustainability, 8 (4), 373-405.

Coulson J., Roberts P. Taylor I., 2015, University planning and architecture. The search for perfection, Routledge, New York.

Cox A.M., Benson Marshall M., Burnham J.A.J., Care L., Herrick T., Jones M., 2020, Mapping the campus learning landscape, Pedagogy, Culture \& Society, 1-19, https://doi.org/10.1080/1 4681366.2020.1788124 (dostęp: 15.05.2020).

Cullen G., 1971, The concise townscape, Van Nostrand Reinhold Company, New York.

Domae L., 2017, Planning the campus with place in mind: a phenomenological exploration of the lifeworlds of community college campuses in British Columbia, praca doktorska, Department of Geography, University of Victoria.

Fikus M., 2002, Instytut: zatożenia autorskie, Architektura-murator, 1, 13-17.

Franaszek P. (red.), 2020, Kampus 600-lecia Odnowienia Uniwersytetu Jagiellońskiego, Wydawnictwo Uniwersytetu Jagiellońskiego, Kraków.
France D., Whalley W.B., Mauchline A., Powell V., Welsh K., Lerczak A., Park J., Bednarz R. 2015, Enhancing fieldwork learning using mobile technologies, Springer, Cham.

Gehl J., 2009, Życie między budynkami. Użytkowanie przestrzeni publicznych, Wydawnictwo RAM, Kraków.

Göçer Ö., Göçer K., Başol A.M., Kıraç M.F, Özbil A., Bakovic M., Siddiqui F.P., Özcan B, 2018, Introduction of a spatio-temporal mapping based POE method for outdoor spaces: Suburban university campus as a case study, Building and Environment, 145, 125-139.

Griffith J.C., 1994, Open space preservation: an imperative for quality campus environments, The Journal of Higher Education, 65 (6), 645-669

Gumprecht B., 2007, The campus as a public space in the American college town, Journal of Historical Geography, 33, 72-103.

Gyurkovich M. (red.), 2016, Hybrid urban structures, Wydawnictwo PK, Kraków.

Jacobs J., 1969, The economy of cities, Vintage Books, New York.

Jacobs J., 2000, The nature of economies, Vintage Books, New York.

Jędrychowski I. (red.), 2007, Atlas otoczenia Kampusu 600-lecia odnowienia Uniwersytetu Jagiellońskiego, Instytut Geografii i Gospodarki Przestrzennej Uniwersytetu Jagiellońskiego, Kraków.

Han K.T., 2007, Responses to six major terrestrial biomes in terms of scenic beauty, preference, and restorativeness, Environment and Behavior, 39 (4), 529-556.

Kanhere S.S., 2013, Participatory sensing: crowdsourcing data from mobile smartphones in urban spaces, [w:] C. Hota, P.K. Srimani (red.), Distributed Computing and Internet Technology, 9th International Conference, ICDCIT 2013, Bhubaneswar, India, February 5-8, 2013, 19-26.

Kapecki T., 2015, O architekturze szkót wysszych w Polsce na poczatku XXI wieku, Wydawnictwo Politechniki Krakowskiej, Kraków.

Kaplan S., 1987, Aesthetics, affect, and cognition: Environmental preference from an evolutionary perspective, Environment and Behavior, 19 (1), 3-32.

Kaplan R., Kaplan S., Ryan R., 1998, With people in mind. Design and management of everyday nature, Island Press, Washington.

Kidyba M., Makowski Ł., 2017, Samoræqdy wobec smart cities - wyzwania, Chorzowskie Studia Polityczne, 13, 47-74.

Kulawiak A., Szmytkowska M., 2018, Geograficzny aspekt badań nad præestrzeniq publicænq miast w Polsce, Biuletyn KPZK PAN, 271, 75-92.

Landry C., 2013, Kreatywne miasto, Narodowe Centrum Kultury, Warszawa.

Liprini R.M., Coetzee N., 2017, The relationship between students' perceptions of the University of Pretoria's on-campus green spaces and attention restoration. Human Geographies - Journal of Studies and Research in Human Geography, 11 (2), 155-167.

Live Baltic Campus Development Ideas Book, 2017, Live Baltic Campus, Helsinki, http:// livebalticcampus.eu/wp-content/uploads/2017/12/LBC_Development-Ideas-Book.pdf (dostęp: 10.05.2020)

Lucas R., Romice O., 2008, Representing sensory experience in urban design, Design Principles and Practices: an International Journal, 2 (4), 83-94. 
Lynch K., 1960, The image of the city, The MIT Press, Cambridge, MA-London.

Matsuoka R.H., Kaplan R., 2008, People needs in the urban landscape: analysis of Landscape And Urban Planning contributions, Landscape and Urban Planning, 84 (1), 7-19.

Maurrasse D.J., 2001, Beyond the campus. How colleges and universities form partnerships with their communities, Routledge, New York-London.

McFarland A.L., Waliczek T.M., Zajicek J.M., 2008, The relationship between student use of campus green spaces and perceptions of quality of life, Hort Technology, 18 (2), 232-238.

Motak M., 2012, Historia rozwoju urbanistycznego Krakowa w zarysie, Wydawnictwo PK, Kraków. Oldenburg R., 1999, The great good place: cafés, coffee shops, bookstores, bars, hair salons, and other hangouts at the heart of a community, Marlowe \& Company, New York.

O'Rourke V., Baldwin C., 2016, Student engagement in placemaking at an Australian university campus, Australian Planner, 53 (2), 103-116.

Osmond H., 1957, Function as the basis of psychiatric ward design, Mental Hospitals, 8, 23-27.

Ozbil A., Gocer O., Bakovic M., Gocer K., 2018, A quantitative investigation of the factors affecting patterns of occupation in a suburban campus: the case of Ozyegin University in Istanbul, Archnet-IJAR: International Journal of Architectural Research, 12 (2), 98-125.

Salama A.M., 2008, When good design intentions do not meet users expectations: exploring Qatar University campus outdoor spaces, Archnet-IJAR: International Journal of Architectural Research, 2 (2), 57-77.

Seitz C.M., Reese R.F., Strack R.W., Frantz S., West B., 2014, Identifying and improving green spaces on a college campus: a photovoice study, Ecopsychology, 6 (2), 98-108.

Sikorski M., Jackowski S., Matysiak K., 2020, Przestrzenie uniwersytetu. Trendy. Wirje. Standardy projektowania, Wydawnictwa Uniwersytetu Warszawskiego, Warszawa.

Siu Yu Lau S., Gou Z., Liu Y., 2014, Healthy campus by open space design: approaches and guidelines, Frontiers of Architectural Research, 3 (4), 452-467.

Sommer R., 1967, Sociofugal space, American Journal of Sociology, 72, 654-660.

Speake J., Edmondson S., Nawaz H., 2013, Everyday encounters with nature: students' perceptions and use of university campus green spaces, Human Geographies - Journal of Studies and Research in Human Geography, 7 (1), 21-31.

Spooner D., 2014, Enhancing campus sustainability through SITES and socially equitable design, Planning for Higher Education Journal, 42 (4), 30-45.

Whyte W.H., 2018, The social life of small urban spaces, Project for Public Spaces, New York.

Winnicka-Jasłowska D., 2008, Internet-based study on users' needs. Students' functional and spatial needs in facilities of architecture faculties at technical universities in Poland, ACEE Architecture, Civil Engineering, Environment, 1(1), 47-53.

Winnicka-Jasłowska D., 2012, New outlook on higher education facilities. Modifications of the assumptions for programming and designing university buildings and campuses under the influence of changing organizational and behavioral needs, ACEE Architecture, Civil Engineering, Environment, 5(2), 31-38.
Winnicka-Jasłowska D., 2015, Quality analysis of Polish universities based on POE methoddescription of research experiences, [w:] M. Antona, C. Stephanidis (red.), Universal access in human-computer interaction. access to learning, health and well-being, Springer, Cham.

Żabicki P., 2016, Urbanistyka i architektura szkolnictwa wyæssego w Polsce w kontekscie idei zrównoważonego rozwoju, [w:] K. Pobłocki, B. Swiątkowska (red.), Architektura niezrównoważona. Synchronizacja - projekty dla miast præysztości, Fundacja Nowej Kultury Bęc Zmiana, Warszawa, 134-153.

Żórawski J., 2017, O budowie formy architektonicznej: skrócone ujecie opracowane przez Bohdan Lisowskiego, Politechnika Krakowska, Kraków.

Jarostaw Dziatek (ORCID 0000-0002-2670-8862)

Magdalena Miśkowiec (ORCID 0000-0002-1657-7256)

Agnieszka Świgost-Kapocsi (ORCID 0000-0002-3229-0271)

Krzysztof Gwosdz (ORCID 0000-0002-6670-2422)

Uniwersytet Jagiellonski

Wydziat Geografii i Geologii

Instytut Geografii i Gospodarki Præestrzennej

ul. Gronostajowa $7,30-387$ Kraków

jarek.dzialek@uj.edu.pl

Barttomiej Hominski (ORCID 0000-0002-3509-2078

Politechnika Krakowska

Wydziat Architektury

Katedra Urbanistyki i Architektury Struktur Miejskich

ul. Podchorażych 1, 30-084 Kraków

bhominski@pk.edu.pl 
